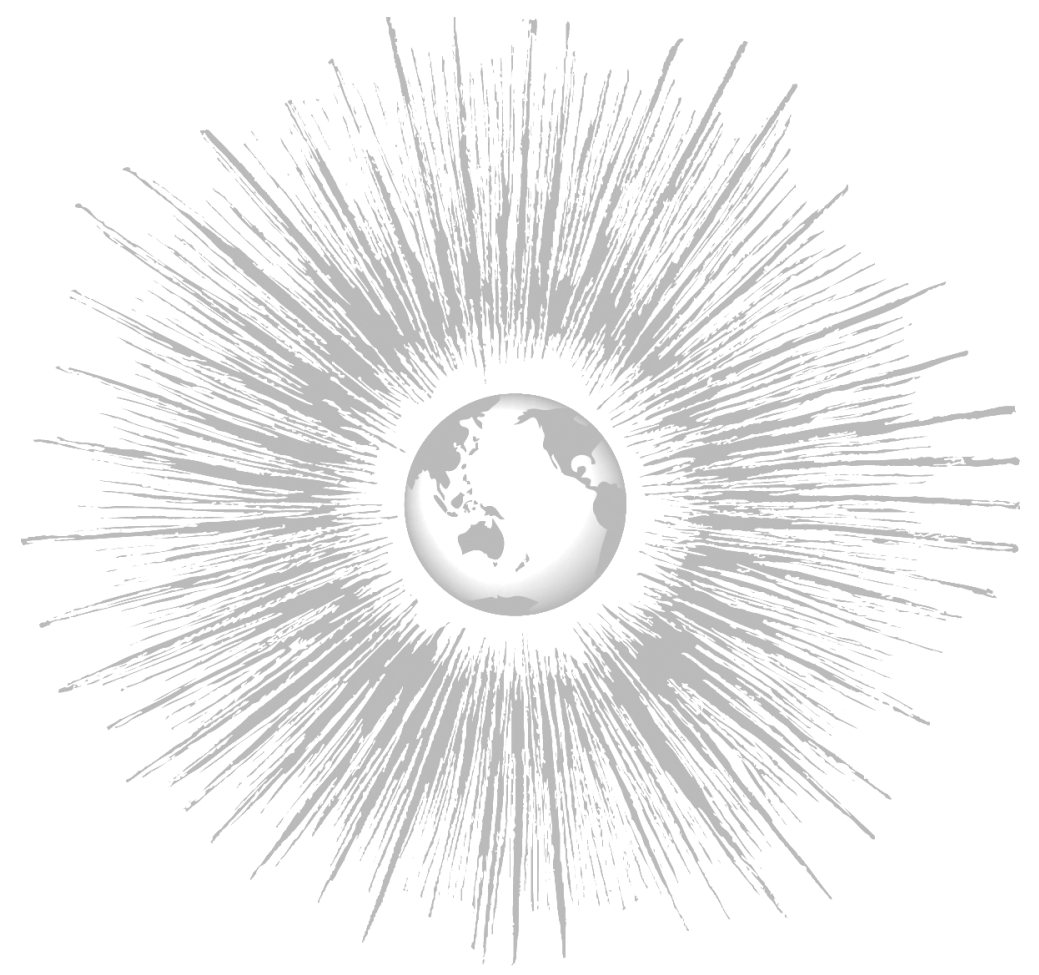

ABSTRACT:

This article is the fifth in a series in which the political careers of civilizations/world systems receive snapshot codings of their overall power structures at feasible intervals. The narratives are produced by collating histories with large frames of reference. The coding are done using a nominal variable, polarity with seven available values. Previous articles in the series have examined the Indic system 550 BC-AD I800, the Far Eastern 1025 BC-AD I850 the Southwest Asian C. 2700-1500 BC, and the Northeast African c. 2625-1500 BC. The Northeast African and Southwest Asian systems and sequences merge $\mathrm{c}$. $1500 \mathrm{BC}$ to form the Central system. In the current article, the power structure of the Central Civilization/ World System is appraised over its first 800 years at $\mathrm{IO}-$ year intervals, from $\mathrm{I} 500 \mathrm{BC}$ to an arbitrary stopping point of $700 \mathrm{BC}$.

The systemic power structure is evaluated in terms of its predominant forms and

\section{The Power Configuration Sequence of the Central World System, 1500-700 BC}

David Wilkinson

\begin{abstract}
$A$ nalysis of extant, past, future and alternative power structures of the world $\mathbf{A}_{\text {system has been a public and intellectual issue since the end of the Second }}$ World War, with its accompanying drastic reduction in the membership of the great-power oligarchy. Fox (1944) speculated on alternative futures-a "Big Three" three-superpower system (US, UK, USSR; perhaps later US, Germany, USSR) vs. a "Big Two" bipolar structure (US, USSR). Kaplan (1957) theorized differing patterns of state behavior in world systems with two vs. many great powers. Rosecrance (1963) reviewed world system history 1740-1960 in terms of epochs of unipolarity, bipolarity, tripolarity and multipolarity. Wallerstein (1983, 1984) proposed a reading of world system history from I6I8 in terms of an alternation between hegemony and multipolarity. More recently, the collapse of the Soviet Union has led to discussions of the consequences and possible transformations of a unipolar world power structure, by, among others, the current author (Wilkinson, 1999b).

World-system power structure analyses are thus generally undertaken with a timescale shorter than 500 years. But there are at least five thousand years of world system history (Frank and Gills, eds., 1993), replete with power struggles and power structures. Surely by collecting and examining this immense store of potential data, we can improve our understanding of the present and future of the world system, as well as of its past.
\end{abstract}

David Wilkinson

Department of Political Science

University of California, Los Angeles

4289 Bunche Hall

Los Angleles, CA 90095-1472

dow@ucla.edu

http://www.sscnet.ucla.edu/polisci/

JOURNAL OF WORLD-SYSTEMS RESEARCH, X, 3, FALL 2004, 655-720 http://jwsr.ucr.edu/

ISSN $1076-$ I56X

(C) 2004 David Wilkinson 
There are many interesting topics, questions and hypotheses that might be addressed in this broader context. For instance:

I. Is it the case that all world systems tend to increase in centralization over time, moving e.g. from feudalism to states-systems to universal empires (and thence perhaps to ossification or collapse)? (Cf. Wight 1977, Spengler 1926-1928, Toynbee 1934-1954, Melko 1969.)

2. Is it rather the case that all such systems display cycles of centralizationdecentralization, especially between a unifying world state and anarchy, with no normal "resting point" or terminus ad quem? (Toynbee, 1961)

3. Is a many-great-power ("multipolar") structure the norm? (Gulick, 1955)

4. Is an alternation between unipolarity, brought about by progress localized to one state, and multipolarity, restored by an alliance of the other major powers, the norm? (Wight, 1946; Ranke, 1950; Gulick, 1955)

5. Is tripolarity "inherently unstable," tending to resolve unpredictably to bipolarity? (Fox, 1944)

We can now begin to address these questions, and others, by reference to the very long term. The empirical and comparative-historical study of very large-scale sociopolitical phenomena, under such labels as "civilizations," "world systems," and "macrosocial systems," continues to make progress, as recent work by Brecke (2000, 200I), Chase-Dunn, Manning and Hall (2000), Chase-Dunn, Pasciuti, Alvarezand Hall (Forthcoming), Cioffi-Revilla (200I), Cioffi-Revilla and Landman (1999), Cioffi-Revilla and Lai (1999), Hui (2000, 200I, forthcoming), and Thompson (2000, 2002) attests.

I have for some years been working on developing data and, to a much lesser extent, testing theory concerning the political structures, the power configurations, of civilizations or "world systems," exploring typologies for such structures, locating the sequences of such configurations over very long durations, and developing and testing hypotheses about the expected succession of such sequences.

This paper continues this effort, first presenting data on one world system, then searching for theories consistent with the data.

What are these "civilizations," or "world systems"?*

* Editor's Note: In earlier work Wilkinson (1987) makes it clear that he is defining civilizations/world systems as networks of interacting states (with cities) that make alliances and war with one another.

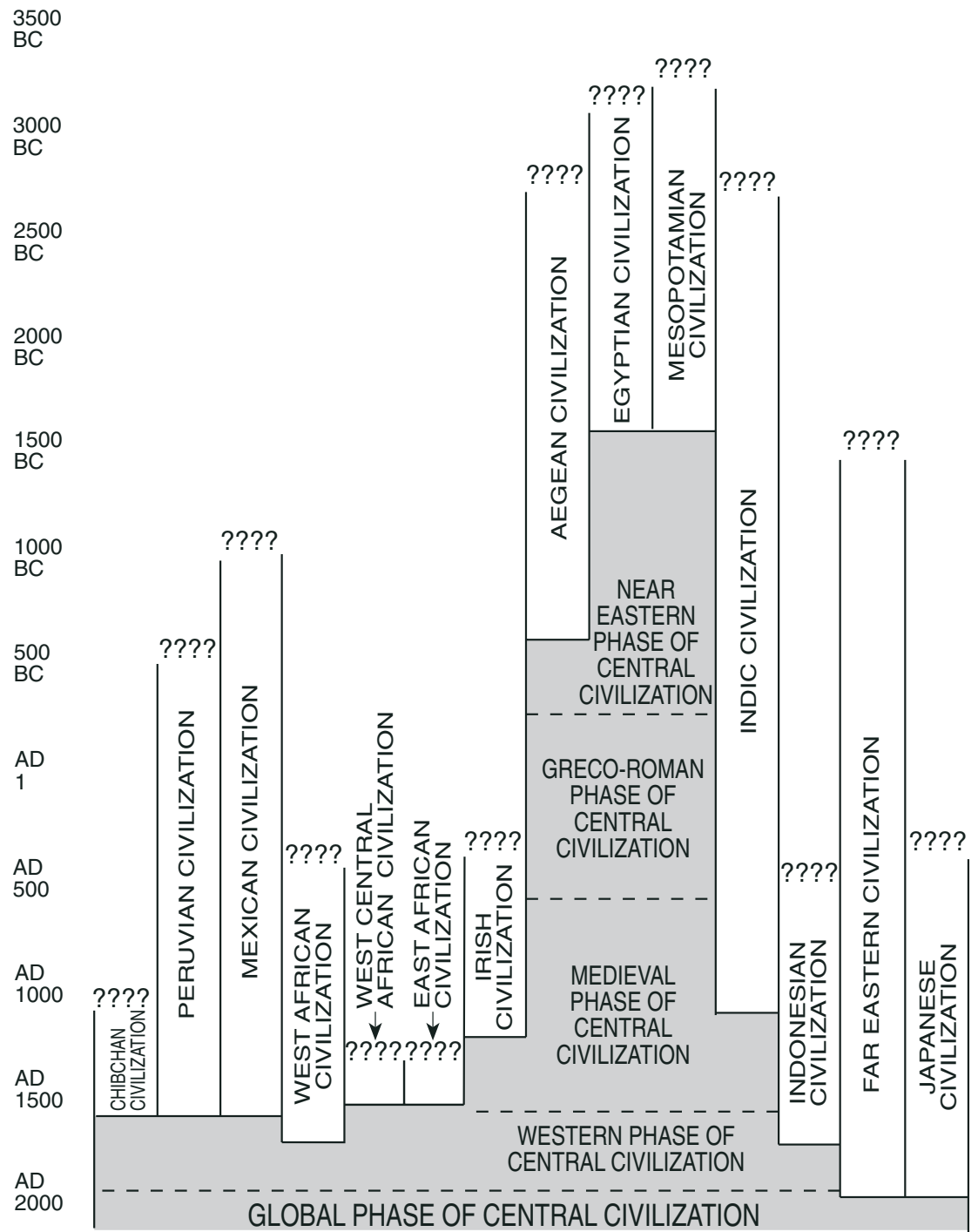

This figure illustrates the successive incorporation of autonomous civilizations into a larger, composite "Central civilization" (in grey). ???? = Transitions to civilization took place no later than this data for this case.

Figure $\mathrm{I}$ is a chronogram which begins at the top of the page. As one goes downward on the page, and forward in time, entities begin to appear on the chart. These are the classic or primary civilizations or world systems, Egyptian 
Figure 2 - Alterations Between States Systems and Universal Empires

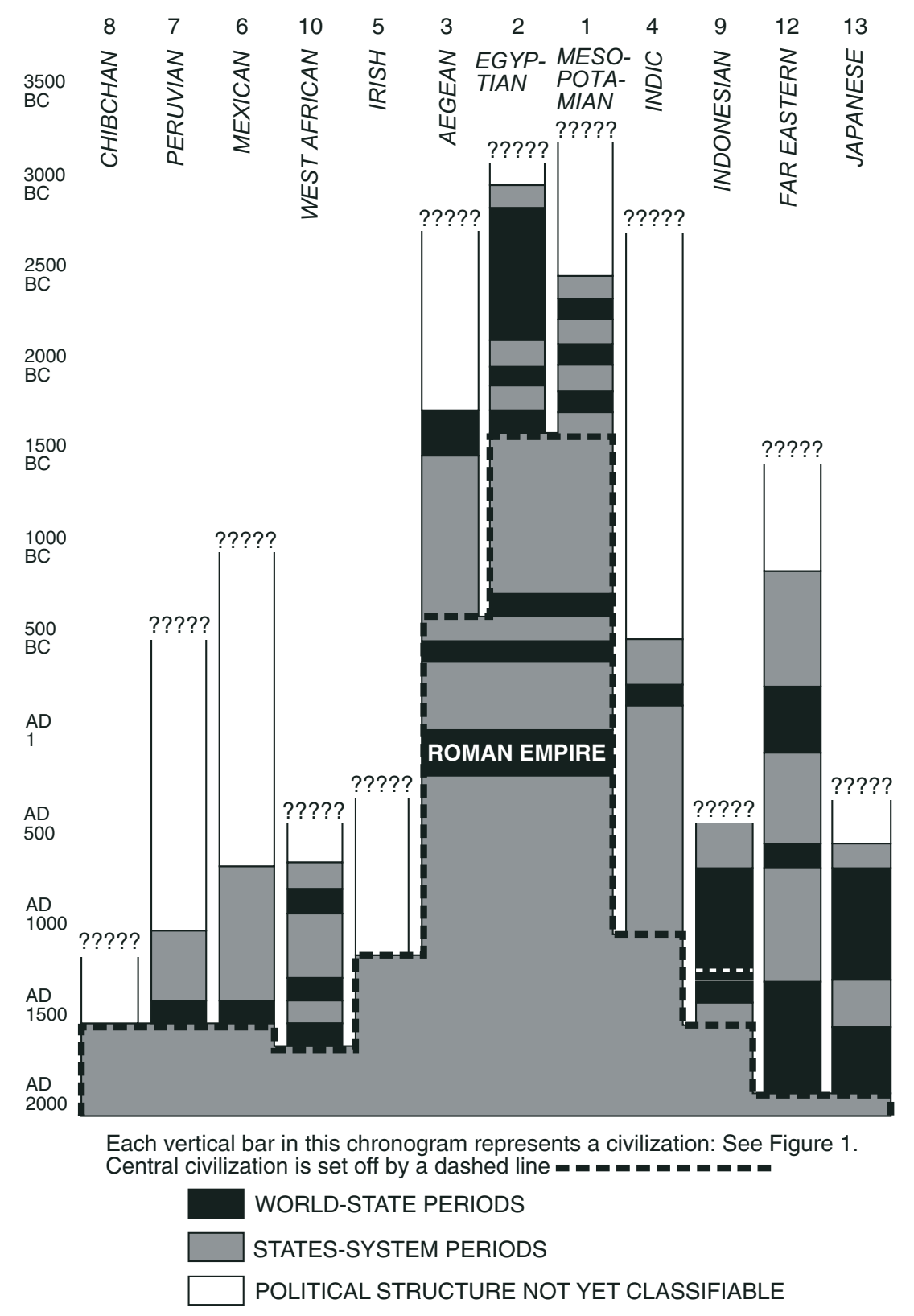

and Mesopotamian, to begin with, then a collection of others-all of the largest, plus some of the smaller ones-arranged roughly west to east, left to right.

Civilizations/world systems come into existence at some point in space, and at some moment in time. The moment of origin is usually uncertain-the question marks indicate that uncertainty. World systems have coexisted on the globe for some period, and then merged into larger entities through long-term growth, collision and fusion.

The I4 particular systems distinguished here (and there are in history several more, usually small ones, not shown on the chart) when viewed at their origins mostly reflect those "civilizations" which have been generally recognized by civilizationists. After about 1500 BC, however, the chart reflects my own view that a composite world system, here called the "Central" system and shown shaded grey, arose in the Near East by way of the fusions of two previously separate politico-military networks, the Mesopotamian and Egyptian. Over its entire duration, "this Central civilization, at first dominated by Near Eastern powers ("Near Eastern Phase"), next by Mediterranean powers ("GrecoRoman Phase"), then by Muslim and Christian states from both previous cores ("Medieval Phase"), and next by West European and Atlantic powers ("Western Phase"), ultimately expanded to the global scale which it enjoys today ("Global Phase"). Thus after AD I500, the chart reflects the world systems view that Western expansion globalized its system, incorporating all the others, previously autonomous, into its own politico-economic structure.

My specific research interest is to represent and analyze the power configurations or political structures of these world systems at different moments in their careers. Figure 2 gives a preliminary look at what I have in mind. The shadings in Figure 2 represent values of a dichotomy which answers the question (for a slightly different set of civilizations) : at a given moment in time, was a world system structured as a system of independent states, or was it united in a universal state or empire? The grey areas represent the answer "system of states." The black areas represent the answer "universal empire." The unshaded areas represent the ever-necessary alternative "don't know."

Earlier versions of Figures I and 2 were used in a previous paper ("Kinematics of World Systems," 1986) to test the theories of several noted civilizationists: Spengler (1926-28), Bagby (1958), Quigley (196I), Melko (1969), and Toynbee (original version, 1939-46, and revised version, 196I). That paper concluded that Toynbee's revised "Helleno-Sinic" model (from his "Reconsiderations") best fit the data of actual alternations between "empires" and "states systems" in civilizations.

Since producing Figure 2, I have been attempting to deal with the obvious concern that a dichotomous variable-Empire vs. States System-underrep- 
Figure 3 - Civilization/World System Power Configurations

\section{Phase I: Two Configurations}

1. States System

2. Universal Empire

Phase II: Seven Configurations
0. Nonpolarity
4. Unipolarity (Non-hegemonic)
1. Multipolarity
5. Hegemony
2. Tripolarity
6. Empire
3. Bipolarity

resents intriguing complexities of power structure. For the next step in data collection I elected to try a heptachotomy, a seven-valued nominal power configuration variable, as shown in Figure 3.

The values of this variable included several configurations long of interest to political scientists and world-systems analysts. In addition to empire, a unified, centralized, usually bureaucratized systemwide structure, I look for weaker forms of systemwide inequality and domination, namely hegemony (a centralized, nonunified structure of internally autonomous subject-ally states and warlords led by a single superpower-overlord), and nonhegemonic unipolarity (with one superpower, as in the world today, unable or disinclined to induce general followership among the weaker states). I have furthermore looked for variation in the number of great powers, distinguishing bipolarity (with two great powers, or superpowers, as during the Cold War) from tripolarity (with three great powers), multipolarity (more than three great powers, as in the world system during say 1815-1945), and nonpolarity (no great powers but many small independent states). These distinctions are developed in some detail in Wilkinson, I996 and 1999b. Hegemony is a condition of special concern to Wallersteinian theory; all the other forms have been variously located in Western history, or speculated upon, by Ranke, Fox, Wight, Kaplan, Rosecrance and others.

Surveying the world systems on this much more complex variable is taking a long time.The current article is one in a series in which summary narratives of the political careers of civilizations/world systems are employed to generate "snapshot" codings of their overall power structures at feasible intervals. The narratives are produced by collating histories with large frames of reference.

Previous articles and papers in the series have examined the Indic system

\section{Figure 4 - The Field of Action of Central Civilization}

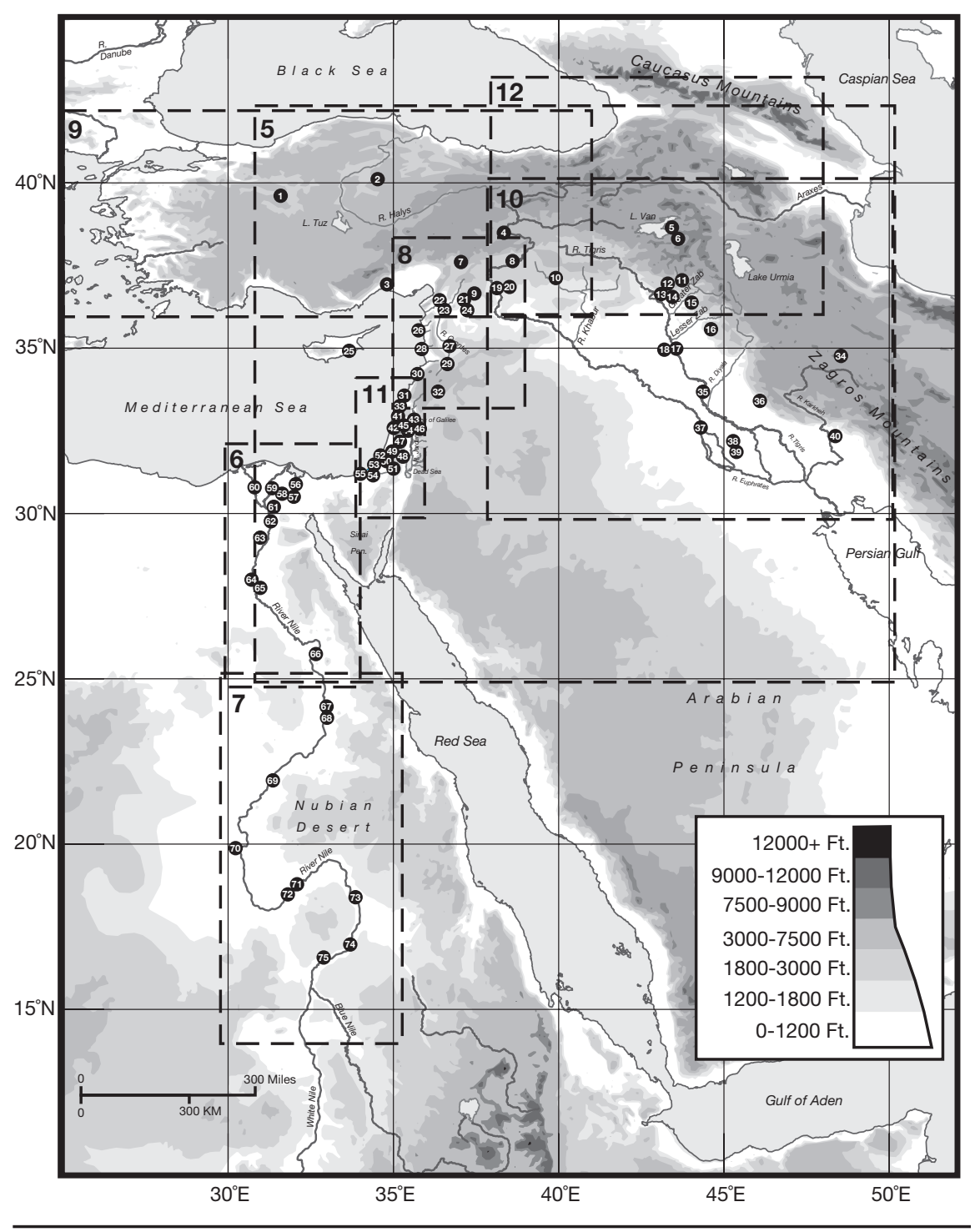

Note: Large font boldface numbers refer to submaps which are figures 5-12 in this text.

550 BC-AD I800 (1996), the Far Eastern I025 BC-AD I850 (I999a), the Mesopotamian/Southwest Asian C. 270-I500 BC (200I), and the Egyptian/Northeast African C. 2625-I500 BC (2004). The latter two systems and sequences merge c. I500 BC to form the "Central" system (Wilkinson, 1987). 
It is this "Central" civilization or world system which is discussed in the current paper. It emerges in the Middle East, as indicated in Figure I, via the fusion of two previously separate politico-military networks, the Mesopotamian and Egyptian, and steadily expands to today's global scale. During the period $1500-700 \mathrm{BC}$, however, the Central system is far more contained, its major expansion being northwestward into Anatolia. The region examined in this paper is shown in Figure 4. (The expansion of the Central system is discussed in greater detail in Wilkinson, 1987; its spatio-temporal boundaries, internal and external, I500$700 \mathrm{BC}$, are considered in more detail in Appendix I below.)

The current paper will inspect and appraise the first 800 years, or roughly the first quarter of the entire duration, of the ongoing Central system, now over 3500 years old, at io-year "snapshot" intervals.

Looking the Central system as a whole, this earliest period, $1500-$ $700 \mathrm{BC}$ is one in which many areas served as power centers, some for most of these centuries (Egypt, Mesopotamia), others more briefly (Iran, Anatolia, Syria, Armenia, Nubia). The most persistent large states, from the systemic point of view, were Egypt, Assyria and Babylonia. Less durable but very powerful in their time were the
Figure 5 - Cities and Powers of the Central World-System

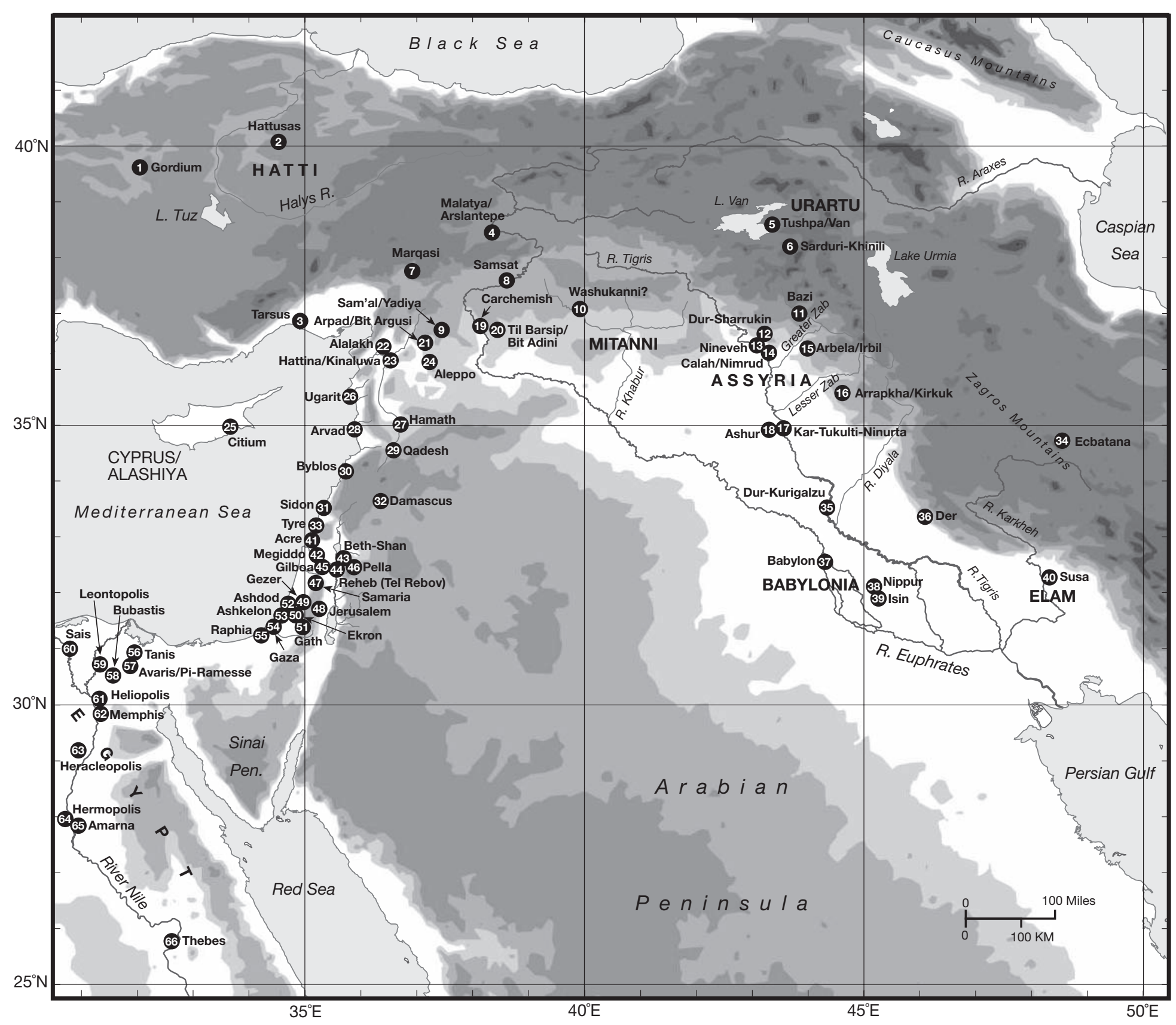


Hittite Empire ("Hatti"), Mitanni, Urartu, and Elam (see Figure 5). Assyria, Egypt and Hatti occasionally seemed on the verge of "rolling up the system," but none in fact established an imperial order in this period: Assyria was the most frequent contestant, but Egypt came closest; the position of Egypt and Hatti was strongest earlier in the period, that of Assyria later.

Assessment of systemwide power structures for $1500-700$ BC is greatly complicated by the absence of any agreed-on systemwide chronology, and further complicated by dissensions over regional chronologies. Periodic appraisals of polarity are bound to be influenced by decisions as to which regional chronologies to use in collating a systemwide chronology. I have made certain choices; these are discussed in Appendix II.

There is no scholarly consensus on the spellings of many royal names from this epoch, and overall consistency would be hard to achieve and probably not worth attempting. Some rulers are well known by Greek versions of their names, which are used here accordingly (e.g. Semiramis), while others were unknown to the Greeks (e.g. Shutruk-Nahhunte). Unwary readers should realize that Amenhotep $=$ Amenhotpe $=$ Amenophis, Twosre $=$ Tawosre $=$ Twosret; common sense will no doubt inform that Sheshonq=Shoshenq=Shoshenk. Even a vigilant reader might not realize that Piankhy=Piy, or, a fortiori, that Methusastratus =Ashtart. $\mathrm{I}$ have tried to remark such extreme cases, and otherwise follow the form of my main source on any reign.

The available sources are very uneven, usually most detailed when consisting of records left behind by boastful victors and conquerors like Tuthmosis III and Ramses II and III of Egypt, Suppiluliumas I of Hatti, or Shalmaneser III of Assyria.

Silences in the record may accordingly indicate either state fragmentation and economic regression or collapse, or a period of military quiescence and concentration on internal affairs with status quo policies displacing foreign policies of imperialism. Absent positive evidence (e.g. of the collapse of the Hittite empire c. І2о0 вC), or strongly asserted specialist opinion, I have tended to interpret brief silent periods as "introverted," and long silent periods with later attested reigns (e.g. Kassite Babylonia) as also "introverted," but longer silences not later put in order (e.g. the 300-year gap between Middle Elamite and NeoElamite records) as regressive, representing collapses of state power rather than an inward focus of state policy.

\section{THE CODING PROCESS}

The information provided for each decade describes behavior of that time period, and implies the coding, or change of coding, at the end of the decade; the coding applies, not to the entire decade, but to the single year by which it is dated.
The relevant sector of the field of action for coding purposes is whatever area contains powers which seek to extend or defend their sway, whether by trading, plundering, subjugating, colonizing, deporting, destroying, or organizing provinces. This "relevant sector" is not stagnant; in the period studied here it both expanded (westward into Anatolia, northeastward into Transcaucasia, and southward into Nubia) and contracted (temporary elimination of Anatolian power by Sea Peoples).

A "nonpolarity" coding would be rejected for any period in which no "great power" behavior is detected. An "empire" coding is rejected for any period in which the vast majority of the system's territory and population is not under the control of a single centralized state. The historical narratives of great power interaction provide the evidence for distinguishing the other five "intermediate" codings of multipolarity, tripolarity, bipolarity, unipolarity and hegemony. A "hegemonic" coding would be produced by e.g. a single state making a claim that the rest acknowledged its supremacy, but only if such a solitary claim were combined with tributary, placatory, submissive, followership behaviors on the part of other states, especially former great powers. Where two or more states assert and evince such spheres of influence, of comparable dimensions, bipolar, tripolar and multipolar codings are appropriate, depending upon the numbers of such states and spheres. Evidence of non-hegemonic unipolarity would be found where e.g. only a single state makes supremacy claims, and manages to extend its sphere of influence disproportionately to that of any other state, but its claims are nonetheless resisted or ignored by many other states. Even without any explicit diplomatic or monumental claim, the recorded sphere and results of politico-military operations provides significant evidence of the relative status of states at various moments in the system's history.

States become relevant to a coding when they appear in the histories, ordinarily first in the histories of already established great powers, especially their neighbors, and cease to be relevant when they disappear from such histories, even their own. This is especially true of the "great powers" upon whose existence and relations the "intermediate" codings most depend. E.g.: when evidence of the influence, and even the existence, of Elam disappears not just from the histories of Assyria and Babylonia but from the histories of Elam itself, Elam is no longer treated as a Central system great power.

Militarily speaking, Syria-Palestine is in this epoch usually the crucial cockpit of the entire Central system, where the surrounding powers seek to extend or defend their interest vis-à-vis one another, and events here are of particular importance in assessing the relative power of all the main actors of the time; far more so, for instance, than are Nubia or western Anatolia, which provide evi- 
dence only of the regional status of Egypt and Hatti respectively. Accordingly, the narrative gives special attention to the Syro-Palestinian gains and losses made by the great powers.

\section{NARRATIVE AND CODINGS I500-700 BC}

Around $1500 \mathrm{BC}$, there were several notable great powers, as well as some once-and-future great powers, in the Central system: Egypt, Mitanni, Hatti, Babylonia, Assyria.

In Egypt, Amenhotep I (1514-I493; I8 ${ }^{\text {th }}$ Dynasty of the New Kingdom period) assembled a creative elite and presided over a cultural and architectural florescence, with major building at Karnak near Thebes (see Figure 6). Egypt extended its fortifications in Nubia south of the Second Cataract (see Figure 7). Egypt had campaigned into Syria, perhaps even to the Euphrates (see Figure 8), during the preceding reign (Ahmose), and Mitanni was now included in Egyptian "enemy lists"; still, this was a rather peaceful reign, in which Egypt had only one or two minor campaigns into Nubia. (G:194, 202-203; H:79-80; $\mathrm{Ba}: 223-224)^{*}$

The Hurrian state of Mitanni had emerged as a power centered between the Tigris and Euphrates, south of the Taurus mountains. Mitanni now took advantage of the antagonisms among the small Syrian city-states to extend its influence to Alalakh, Ugarit and the Mediterranean. (G:213; H\&S:I07; Si:34)

Under Telepinus (c. 1525-1500), Hatti had stabilized and partly recovered after a period of imperial contraction. Hittite control was restored from the heartland of central Anatolia to the Euphrates in the southeast; but Telepinus countenanced the secession of Cilicia in southeast Anatolia (as the independent kingdom of Kizzuwadna under Isputahsu; see Figure 9), going so far as to contract an alliance with it. (Bc:IIO-II3)

Babylonia was in the hands of Kassite people. Its ruler maintained the old title of "King of the Whole World"; still, Babylonia (see Figure Io) was in practice relatively unambitious, usually peaceful, stable, well-fortified, prosperous, and diplomatically active in pursuit of the status quo. (D:439)

In Upper Mesopotamia, Assyria, under Puzur-Ashur III (I52I-I498), was a small vassal to Mitanni, but also claimed by Kassite Babylonia. Assyria would remain a minor state for more than a century* (Gd:22-23; H\&S:II2)

The southern marshland of Babylonia was an independent kingdom under the Sealand dynasty.

\footnotetext{
* Editor's Note: See Reference Abbreviations on page 716.
}

\section{Figure 6 - Egypt}

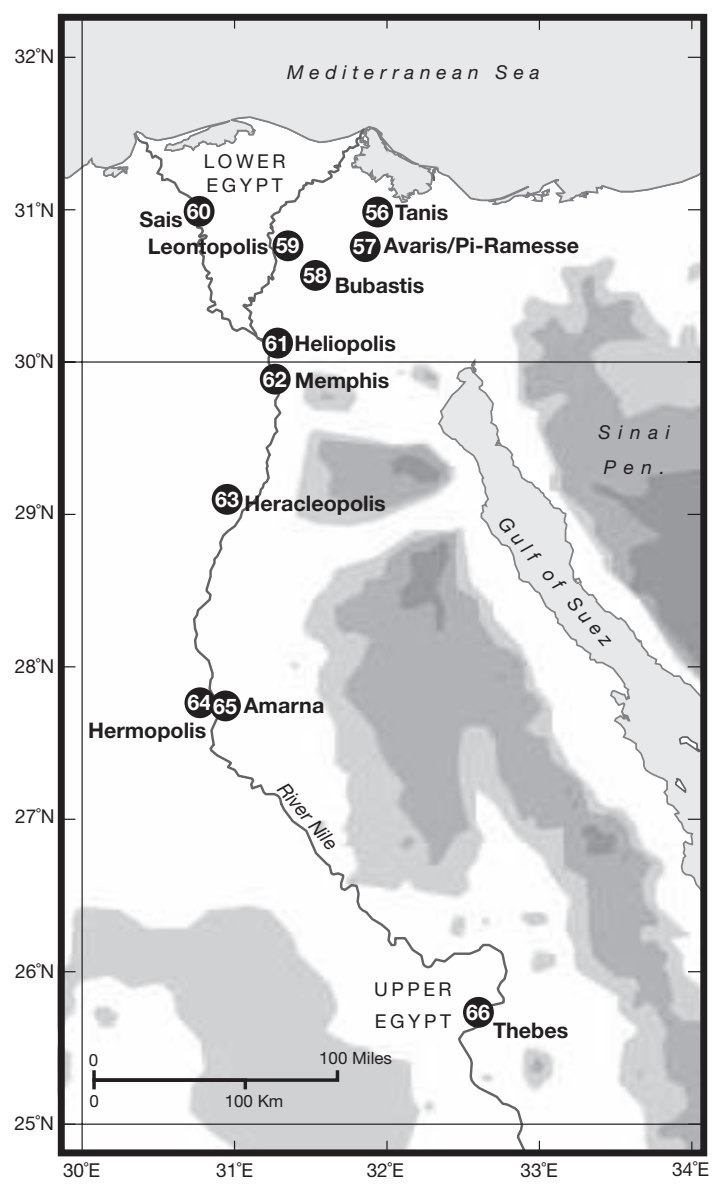

1500 BC. Multipolar: Egypt, Hatti, Mitanni, Babylonia, Kizzuwadna.

After the death of Telepinus of Hatti, a century of usurpations and obscurity followed, with kings Alluwama, Tahurwaili, Hantili II, Zidanta II, Huzziya II, and Muwatallis I occupying the century for unspecifiable periods; but Hatti seems to have maintained stable control over its territory, and to have negotiated with Kizzuwadna on a basis of equality, concluding several treaties to clarify boundaries and settle disputes. (Bc:120-125)

Tuthmosis I of Egypt (1493-I482) pursued an aggressively imperialistic foreign policy. In his second and third years, he conquered Upper Nubia (Kush) to the Third and perhaps the Fourth Cataract. $(\mathrm{H}: 80 ; \mathrm{Ba}: 232,234)$ 


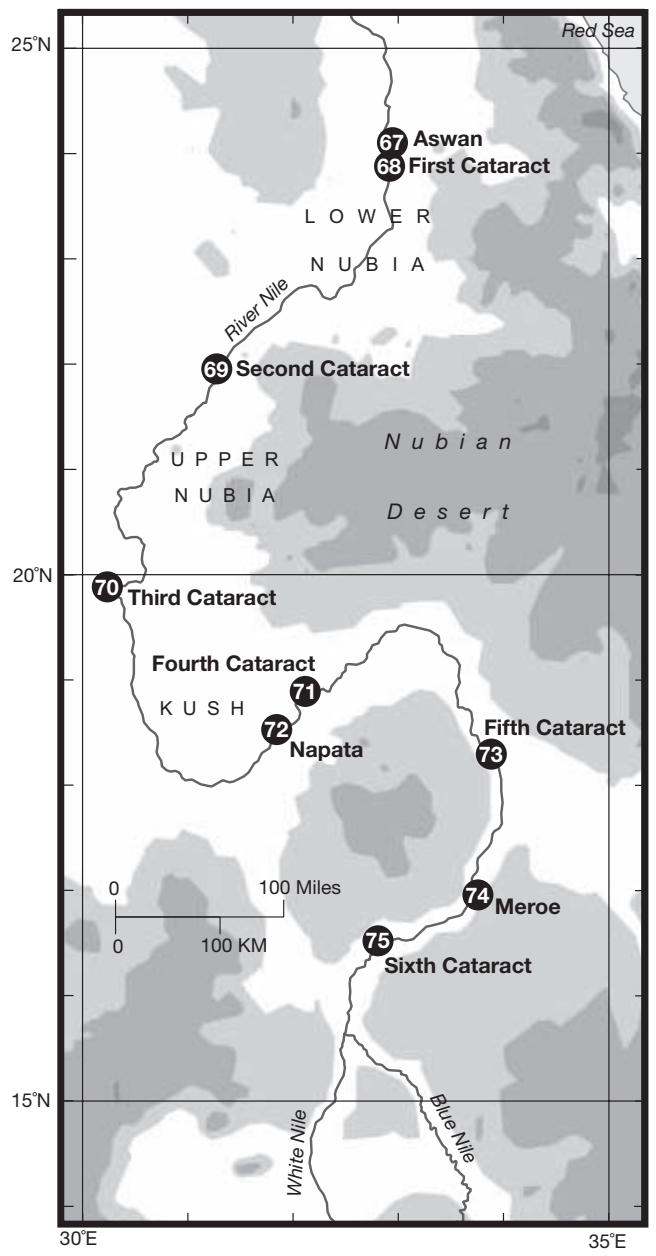

At about this time, Burnaburiash I of Kassite Babylonia signed a border treaty with Puzur-Ashur III of Assyria. (D:442)

1490 BC. Multipolar: Egypt, Hatti, Mitanni, Babylonia, Kizzuwadna.

Tuthmosis I campaigned through Palestine and Syria with little fighting, and set up a boundary stele on the upper Euphrates to assert his claims against the newly consolidated Mitanni power. (G:212; $\mathrm{H}: 80 ; \mathrm{Ba}: 234)$

Tuthmosis II (I482-I479) made shows of force against rebels and raiders in Nubia and Palestine, and built at Karnak. (G:212-213; H:82; Ba:235-236)

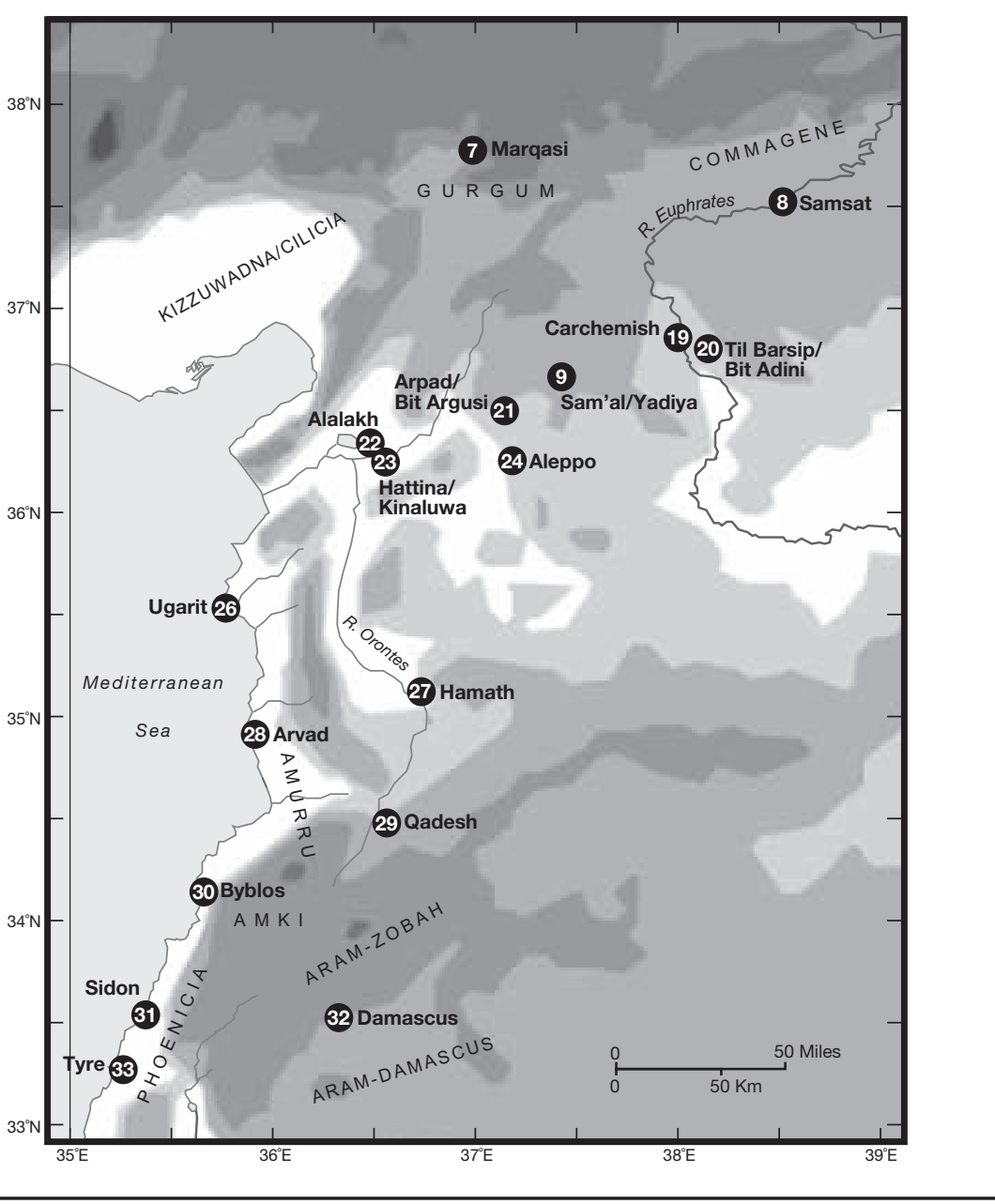

1480 BC. Multipolar: Egypt, Mitanni, Hatti, Babylonia, Kizzuwadna.

The queen-regent (and, later, female king) Hatshepsut (I479-I458) may have abandoned imperialist expansion in favor of trade, monument-building projects, and cultural intercourse. Although she retained a strong army, and used it to stifle resistance in conquered Nubia, Egypt's position in Syria and much of Palestine deteriorated, and Mitanni was allowed to grow in power, all the more as the Hittite kingdom was weakened by civil warfare. $(\mathrm{H}: 82-88$; Ba:238-243) 
Figure 9 - Anatolia

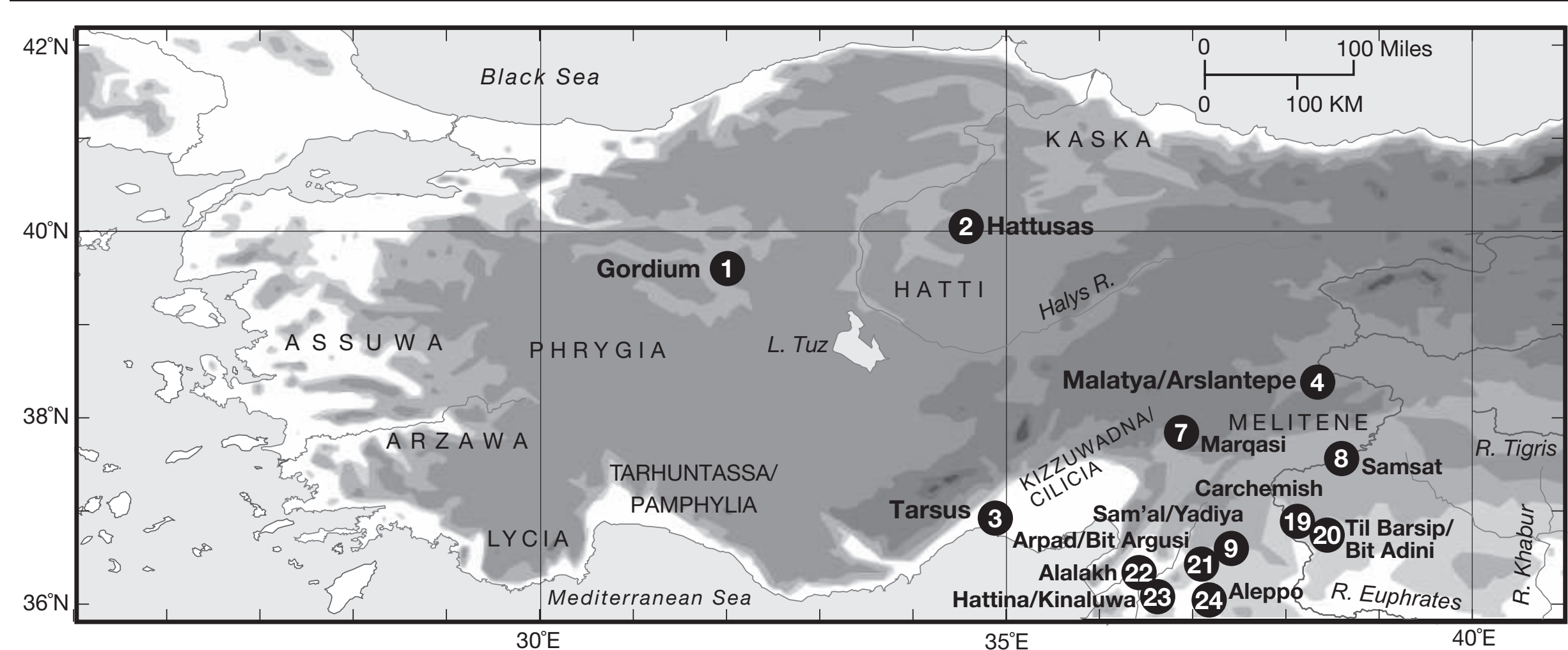

1470 BC. Multipolar: Egypt, Mitanni, Hatti, Babylonia, Kizzuwadna

During Egypt's quiescence under Hatshepsut, Parattarna of Mitanni pushed westward, acquiring hegemony over Aleppo and Alalakh in Syria, and over Kizzuwadna. (Bc:I26-I27)

\section{BC. Multipolar: Mitanni, Egypt, Hatti, Babylonia.}

Tuthmosis III of Egypt (1458-I426), who tried to erase his predecessor Hatshepsut from history, also discarded her unambitious foreign policy. He first faced off against a Syrian coalition, led by Qadesh and aligned with Mitanni. He defeated the coalition in c. 1457, and then besieged, subdued and despoiled Megiddo. However, he failed to pacify the region of Syria-Palestine, where he had to campaign annually; he began by working his way up the Mediterranean coast. (G:213-2I4; $\mathrm{H}: 88-89$; $\mathrm{Ba}$ : 245-246; $\mathrm{Si}: 3 \mathrm{I}-32$ )

Around this time, Ulamburiash of Kassite Babylonia conquered the Sealand. (D:442)
1450 BC. Multipolar: Egypt, Mitanni, Hatti, Babylonia.

The eighth campaign of Tuthmosis III (c. I447) reached the Euphrates. Tuthmosis set up another stele to match that of Tuthmosis I, and then crossed the river to confront Mitanni. He drove the Mitanni army from the field, plundered cities, and took Qadesh. Egypt now controlled the Syria-Palestine coastal strip, and acquired great prestige thereby. Embassies arrived with gifts or "tribute" from the Hittites, Assyria and Babylon. More campaigns against Mitanni followed, with frequent fighting around Aleppo, which however clung to Mitanni. Egyptian hegemonic overlordship was replaced by direct imperial administration in much of Syria and Palestine. (G:215-216; Bc:128-129; $\mathrm{H}: 89$; $\mathrm{Ba}: 246-248 ; \mathrm{Si}: 32)$

The Kassite Agum III crushed a rebellion in the Sealand and remained in control of all Babylonia. (D:443)

About this time, the Middle Elamite titulary "king of Susa and Anzan" begins to be attested at Susa, and the Elamite state may have begun to coalesce again. (C\&S:33) 
Figure 10 - Mesopotamia

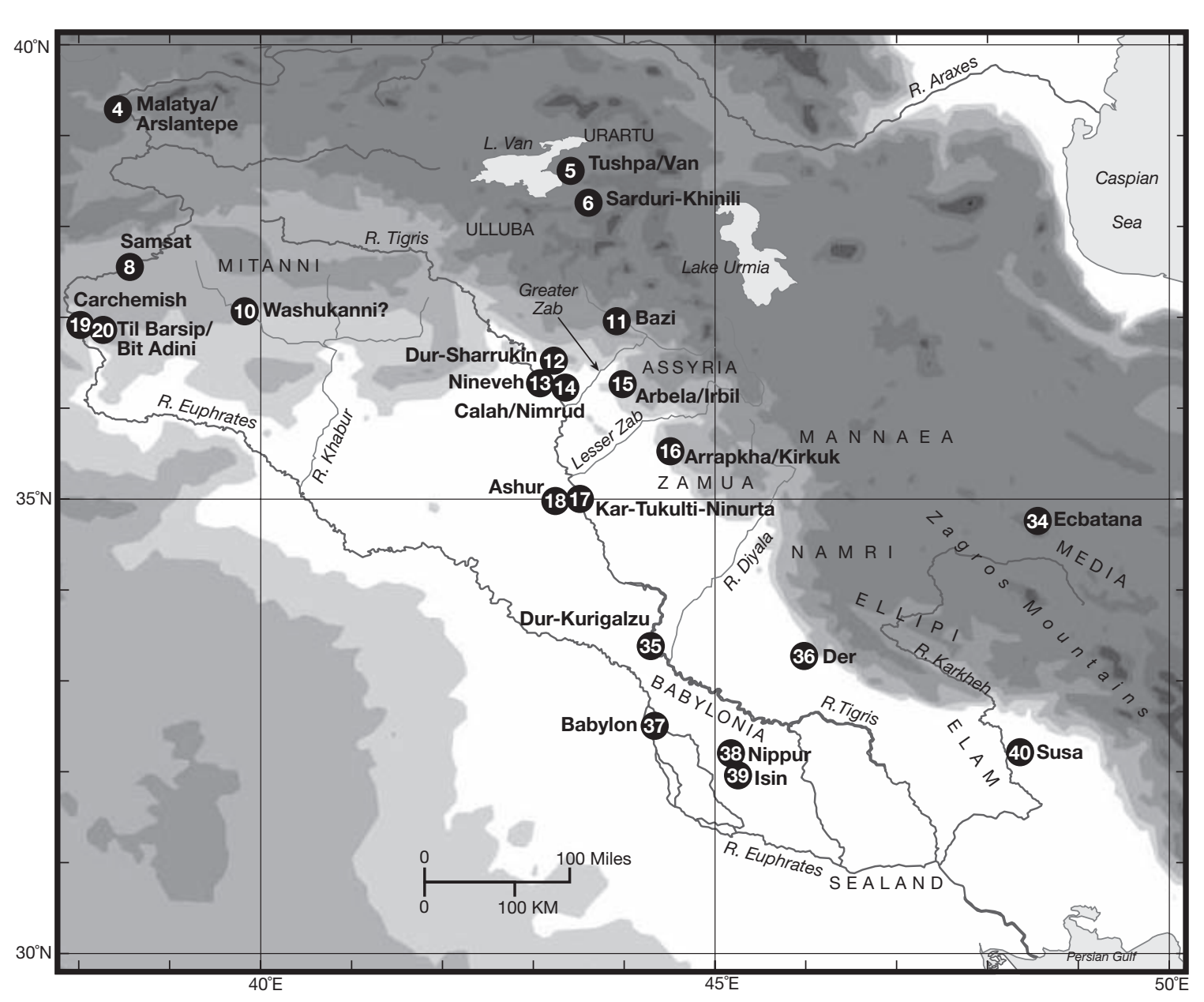

1430 BC. Unipolar: Egypt.

Qadesh revolted from Egypt upon the death of Tuthmosis III, probably encouraged by the energetic Saushtatar I of Mitanni. Amenhotep II of Egypt (I426-I400) worked to restore and maintain the status quo ante. He fought three campaigns in Syria. The first, in his third regnal year, crushed Qadesh. (G:218; Bc:130)

\section{BC. Bipolar: Egypt-Mitanni.}

Assyria had established ties with Egypt; Saushtatar of Mitanni struck at Assyria, looted its capital Ashur, and re-established his suzerainty there. (Bc:149-150)

Saushtatar, and Mitanni's Syrian vassal Carchemish, then incited anti-Egyptian rebellions in Syria and Palestine. In his seventh- and ninth-year campaigns, Amenhotep II again sought to restore Egypt's lost power, but with limited success. Egypt lost control of the area between the Orontes and the Euphrates, but exploited its sea access through the garrisoned port of Ugarit to hold the Orontes line. (G:218-219; H:92; but cf. Ba:252)

Karaindash of Babylonia established diplomatic ties and a marriage alliance with Egypt. (D:465)

\section{BC. Bipolarः Egypt-Mitanni.}

Mitanni ceased its intrigues against Egypt late in the reign of Amenhotep II. The Hittite state revived under Tudhaliyas I/ II, who stormed through Arzawa and Assuwa to the west, looting and conscripting as he went. Tudhaliyas established a new west Anatolian vassal state under one Madduwatta, rebuffed and counterinvaded the Kaska to his north. In organizing his empire, Tudhaliyas may have originated the policy of "human transplantation," i.e. deportation of hostile populations from their home-

\section{BC. Unipolar: Egypt.}

Tuthmosis III conquered Nubia to the Fourth Cataract, there founding a fortress-town, Napata, to defend the new boundary, where he set up a stele c. 1433. Nubian gold in the amount of 660 pounds a year flowed into Egypt, financing an outreach of foreign influence. Satisfied with the gifts or "tribute" received now from many Asian locations, Tuthmosis otherwise kept the peace and spent his time in extensive temple-building. (G:216-217; Bc:129; H:90-9I; $\mathrm{Ba}: 248,252 ; \mathrm{St}: 30$ ) land to be colonized (resettled) elsewhere. Hatti re-established an alliance with, and perhaps suzerainty over, Kizzuwadna, and did violence to Aleppo, in the Mitanni sphere in northern Syria. Saushtatar's successor Artatama I of Mitanni in turn warmed to Egypt, sent gifts to Amenhotep (as did Hatti), and made overtures for a settlement in Syria. (G:219; Bc:132-157, 236; H:92; Ba:252-253)

Kurigalzu I of Babylonia maintained the alliance with Egypt, and also sent gifts. (D:466-467) 


\section{BC. Unipolar: Egypt.}

Arnuwandas I of Hatti was distracted from imperialism by the need to combat rebellion within the existing empire. Tuthmosis IV of Egypt (I400I390), a builder not a fighter, did some minor symbolic campaigning in SyriaPalestine, but made terms with Mitanni, abandoning north Syria while keeping Palestine and the ports including Ugarit, retracting the Orontes frontier to Qadesh while forfeiting Alalakh, and contracting a marriage alliance with a daughter of Artatama I of Mitanni. In his eighth year Tuthmosis IV did conduct a police action against tribal infiltrators in Nubia, with which commerce was maintained. (G:219-220; Bc: 156-158; H:93; Ba:255-258)

Igi-halki of Elam (c. I400-I380) founded a new dynasty which began the revival of Elamite power. $(\mathrm{P}: 205-207,209)$

\section{BC. Multipolar: Egypt, Mitanni, Hatti, Babylonia, Elam.}

Amenhotep III (1390-1352) had a single war year, his fifth, a campaign in Nubia, perhaps south of the Fifth Cataract. Otherwise his reign was one of peace, remarkable prosperity, and great Egyptian prestige, probably sustained by a policy of using abundant Nubian gold to buy peace, submission, and alliances via dynastic marriages. Amenhotep carried on a temple-building program on a colossal scale, especially in Nubia. (H:94-97; Ba:260, 268)

While the chronology is unclear, Hatti in the next decades apparently suffered severe invasions at the hands of the Kaska to the north. Arzawa to the west, and several other assailants, and lost much territory. (Bc:158-160)

\section{BC. Hegemonic Egypt.}

About 1380 вс (cf. G:223 vs. H:95), Amenhotep III married a daughter of Suttarna II of Mitanni, renewing the Egypt-Mitanni alliance.

Pahir-ishshan, the second king of the Igihalkid dynasty of Elam, married a sister of Kurigalzu I of Babylonia. ( $: 207)$

\section{BC. Hegemonic: Egypt.} blank?

Nothing noteworthy is recorded: happy the world system whose annals are

\section{BC. Hegemonic: Egypt.}

Tudhaliyas III of Hatti (c. I360-I344) campaigned successfully in Anatolia, re-establishing a strong Hittite state. (Bc:16I-167)

Perhaps at about this time, Ashur-uballit I of Assyria (c. I362-1327), a Mitanni vassal, asserted himself as "king" and no longer as "governor." $\mathrm{He}$ politely corresponded with Egypt as a king to king, sending gifts. (Gd:23; H\&S:I13; C\&W:7, I49-150)
Tushratta of Mitanni gave Amenhotep III of Egypt a daughter to wife in his 37th regnal year. Kadashman-Enlil I of independent Babylonia thereupon also provided a wife to Amenhotep III, who shortly died. At his death, Egypt's wealth, power and status were at a peak. The elite was opulent, the regime tolerant and generous, the world friendly, respectful and solicitous. (G:223; Vd:272)

Amenhotep IV (1352-1348), better known by the name of Akhenaten (1348-1338) turned Egypt sharply inward, and preoccupied himself with preparing a religious reformation. His reasons may have been as political as theological: Amenhotep III's most recent temple-building had greatly strengthened the internal political influence of the priesthood of Amun at Thebes, as against the pharaoh. (G:225)

\section{BC. Unipolar: Egypt.}

In his fourth year, Amenhotep IV sent the high priest of Amun into effective internal exile, and began a five-year program of politico-religious innovation. He promoted and reconfigured the sun-disk deity Aten of Heliopolis, to the detriment, first relative and then absolute, of Theban Amun. Amenhotep IV promoted a new set of officials, changed his Amun-based personal name to the Aten-based "Akhenaten," and built himself a new capital (Amarna) far from existing temples and priesthoods. (H:100-IOI; Vd:277)

In his ninth year, Akhenaten suppressed the traditional, and now rival, gods, temples, cults and festivals, and centralized administration in his own hands, as sole intermediary to the sun disk. (G:226-237; Vd:277)

Although he did suppress a revolt in Nubia, vital to Egypt for its gold, Akhenaten was too preoccupied with his cultural revolution to curb the recovery of Hatti under Suppiluliumas I (c. 1344-I322), who worked to isolate and weaken Egypt's ally Mitanni. Even while he cultivated Akhenaten, Suppiluliumas championed a pretender to the Mitanni throne. His ambitious deeds included marrying a daughter of Burnaburiash II, the Kassite king of Babylon, and establishing a son as lord of Kizzuwadna. (Bc:170-I74; Ba:278)

There was a major revival of Elamite prosperity under Humban-numena (1350-I340). (P:209, 2II-2I2; cf. Hz:II2-II3, L:384)

\section{BC. Bipolar: Egypt, Hatti.}

Tushratta of Mitanni attacked a Hatti ally in Syria, and was trounced by Suppiluliumas in a blitzkrieg campaign which conquered Aleppo and all other Syrian vassals of Mitanni except Carchemish. Ugarit revolted from Egypt in favor of the Hittites. Byblos and Amurru (a semi-nomadic south Syrian entity) had both been subject to Egypt; Amurru now submitted to Hatti, and Byblos to Amurru. Suppiluliumas conquered and subjugated Egypt's vassal Qadesh; in Syria, only Damascus remained aligned with Egypt. (Bc:I74-190; H:I02-IO3) 
Perhaps emboldened by the decay of Mitanni and the paralysis of Egypt, Ashur-uballit I of Assyria wrote again to Egypt, now styling himself a great king and an equal, and demanding a large subsidy. Burnaburiash II of Babylon objected that Assyria, once free of Mitanni, ought to have become a Babylonian vassal; but Babylonia, under Aramean nomad pressure, eventually accepted a marriage alliance with Assyria. A Babylonian revolt against this concession of equality killed one king of Babylon, and gave Ashur-uballit the opportunity to intervene to enthrone another, Kurigalzu II (c. 1345-I324). (Gd:24, 28-29; $\mathrm{H} \& \mathrm{~S}: 113 ; \mathrm{C} \& \mathrm{~W}: 7, \mathrm{I} 49-150)$

Amunism began to resurface even while Akhenaten lived. Akhenaten's death was followed by the reigns of the obscure Smenkhkare (1338-1336) and the now very well known Tutankhaten/Tutankhamun (1336-1327), under whom there was a restoration of Amun and abandonment of Aten. Akhenaten's new capital Amarna was abandoned, but in favor of Memphis, whose dominant cult was that of Ptah, rather than Amun's Thebes. (G:237, 24I; H:IO3).Sometime in Tutankhamun's reign, the Hittites raided the Egyptian dependency of Amki in Lebanon. The Pharaoh and his general Horemheb retaliated by a campaign into Syria, seizing Qadesh and stemming the decay of Egypt's influence. $(\mathrm{G}: 242 ; \mathrm{H}: 106)$

Untash-Napirisha of Elam (1340-1300), continuing the Elamite revival, married a daughter of Burnaburiash II of Babylonia, had extensive foreign contacts, and undertook a major building program. (Hz:II3-II9; L:384-385; C\&S:37; P:209, 212-230)

\section{BC. Multipolar: Egypt, Hatti, Assyria, Elam, Babylonia, Mitanni.}

Tushratta of Mitanni attempted to regain some ground against Hatti near Carchemish and Aleppo while Suppiluliumas was fighting the Kaska. Suppiluliumas returned to assail Mitanni and Egypt's Amki. (Bc:190-193)

Upon Tutankhamun's death, his widow Ankhesenamun applied to Suppiluliumas the Hittite for one of his sons to become her husband and ruler of Egypt. While investigating the matter, Suppiluliumas further reduced Mitanni by storming Carchemish; Tushratta was assassinated. (Bc:194-195) The requested prince, Zennanza, was eventually dispatched-twice, indeed, since he was both sent, and assassinated en route. Egypt's vizier Ay took the throne $(\mathrm{I} 327-1323) .(\mathrm{Bc}: 195-198 ; \mathrm{H}: 106)$

Suppiluliumas retaliated by attacking Egyptian south Syria, seizing Qadesh and Amki. He brought back many prisoners, and with them a plague which would afflict Hatti for twenty years to come. Suppiluliumas next installed a pretender on the throne of much-reduced Mitanni, expelling the candidate of florescent Assyria, which had taken over part of Mitanni. (G:242-243; Bc:198204; $\mathrm{H}: 107)$

Resisting Babylonias claim of suzerainty, Enlil-Nirari of Assyria (c. I329I320) fought indecisively with the Kassite king Kurigalzu II (c. 1345-I324). (Gd:3I-32; H\&S:II3)

General Horemheb succeeded to the Egyptian throne (1323-I295), and maintained a generally static frontier against the Hittites in Lebanon. (G:243; $\mathrm{H}: 107)$

About 1322, Suppiluliumas perished of his imported plague, as did his immediate successor Arnuwandas II (I322-I32I) and the Hittite commander against the once-more aggressive Kaska. Mursilis II (132I-I295) succeeded to a rule contested by the Kaska in the north and the Arzawans in the west, and struck north first, in his first year. (Bc:204-209)

\section{BC. Multipolar: Egypt, Hatti, Assyria, Babylonia, Elam.}

In Egypt, Horemheb busied himself dismantling the temples and centralized state of Akhenaten, building non-Atenist temples, and restoring regionalism and localism in the politico-religious structure of the state. (G:243-244)

Mursilis of plague-ridden Hatti campaigned against the Kaska in his second year, then turned west for two years to defeat the Arzawans, destroying the population base of the most troublesome Arzawan state by deportations, and subjugating the rest of Arzawa. Mursilis next refought the Kaska for two years, burning, devastating, massacring. In his seventh year he used intrigue and invasion to replace disloyal Syrian vassals with more dependable ones, and rebuffed an Egyptian-assisted rebellion. In his eighth year Mursilis faced rebellions to the northeast and northwest of the Hatti homeland; in his ninth, the northeast still ablaze, Qadesh rebelled and Assyria seized Carchemish; in his tenth, the northeast was subdued, Carchemish and Qadesh retaken, and new vassal rulers installed in Aleppo and Ugarit. (Bc:209-225) Mursilis systematized the policy of pacification by mass transplantations for which Tudhaliyas I/II provided the model. (Bc:236-238)

Assyria under Arik-den-ili (1319-I308) and Babylonia under Nazimaruttash (1323-I298) continued a seesaw protracted war in which Babylon employed eastern hillmen as its agents. ( $\mathrm{Gd}: 32-33)$

\section{BC. Unipolar: Hatti.}

Mursilis II of Hatti faced two new rebellions in Arzawa in his twelfth year, and put one down with a threat of force and the other with a new appointment. For the rest of this decade, he occupied himself with ephemeral victories in northern campaigns; he may have been at peace with Horemheb of Egypt. $(\mathrm{Bc}: 230-234 ; \mathrm{vD}: 293)$ 
Adad-Nirari I of Assyria (1307-I275) inaugurated a successful imperialist expansion. He soundly defeated Nazimaruttash (1323-I298) of Babylonia and carried out a punitive action against the Zagros hillmen. (MR:275; H\&S:I13; $\mathrm{St}+27)$

\section{BC. Multipolarः Egypt, Hatti, Assyria, Elam.}

In his 22nd year, Mursilis II of Hatti had to face several years of rebellious activity in a previously loyal area, and eventually managed to suppress it. $(\mathrm{Bc} \div 234-235)$

Kadashman-Turgu (I297-I280) of Babylonia apparently avoided renewing Babylonian claims on, and war with, Assyria. (MR:275)

Elamite history becomes obscure and confusing for 75 years after UntashNapirisha. (P\$230-23I)

The succession of another general in Egypt, Ramses I (I295-I294), began a new dynasty (Dynasty 19, I295-II88 BC) which emphasized the cult of Ra of Heliopolis and the importance of Memphis. His son, Seti I (I294-I279) erased Akhenaten, Smenkhkare, Tutankhamen and Ay from the histories, and promoted the cult of Seth of Avaris to equal standing with Ra, Ptah and Amun of Thebes. (G:245-247; H:107-IO9)

Muwatallis II of Hatti (c. I295-I272) put down a rebellion in western Anatolia; in a treaty, he recognized as equals Egypt, Babylon, Assyria, and, curiously, Mitanni. (Bc:247-248) Perhaps about this time, Adad-Nirari of Assyria began to expand west against Shattuara I of Mitanni. (MRः276)

Seti of Egypt faced hostility in Palestine (see Figure II), where Egypt controlled only three fortresses, Beth Shan, Reheb (Tel Rehov) and Megiddo. In his first year he captured Raphia and Gaza, relieved Beth Shan and Reheb from attacks by Hamath and Pella, and captured Acre, Tyre and Pella. In his second year he campaigned to Qadesh. In his third year he campaigned against the Libyans. In his fourth year he fought Hatti near Qadesh. Egypt having measured its ability to control Syria and shown that it reached to the vicinity of Qadesh, Seti made peace with Muwatallis II the Hittite. (G:247; Bc $248-25$; $\mathrm{H}: 109 ; \mathrm{vD}: 295)$

\section{BC. Bipolar: Egypt, Hatti.}

Egypt and Hatti remained at peace. Muwatallis II however prepared for further struggle by moving his capital southward toward Egypt and Syria, from Hattusas in the Hittite heartland of north-central Anatolia to Tarhuntassa in Cilicia. He handed Hattusas and vicinity over to a viceroy, his brother, the future Hattusilis III, who proceeded to repopulate the Kaska-devastated regions. $(\mathrm{B} c$ :25I-255)
Seti of Egypt raided Nubia for slave labor, reopened and improved old gold mines and stone quarries, and embarked on a major temple-restoration and temple-building program. (vD:295)

\section{BC. Bipolar: Egypt, Hatti,}

In Egypt, there began the long and notable reign of Ramses II (I279-I212). In his second year he defeated and conscripted the Sherden pirate raiders. In his fourth year, he campaigned to Tyre and Byblos, and enforced or confirmed the subjection of Benteshina of Amurru, restoring Egyptian hegemony as far as Ugarit. Hatti viewed this as a challenge, and prepared a massive response. (Gः25I-253; Bcะ255-256; H:IIO; vDः297)

Shalmaneser I of Assyria (I274-I245) fought, conquered, pillaged and subjugated the Hurrian mountain principalities of the Uruatri, predecessors of the future state of Urartu (see Figure 12). (MR:279-280; Bt:329)

In his fifth year, c. 1274, Ramses fought the most notorious of the many battles of Qadesh, against Muwatallis the Hittite and his vassals or mercenaries from Mitanni, Arzawa, Dardany, Kaska, Lycia, Cilicia (Kizzuwadna), Carchemish, Ugarit, Qadesh and elsewhere. Victorious in all but reality, Ramses escaped with a reasonable collection of plunder and most of his army, while Muwatallis retook Amurru, replacing Benteshina with his own vassal Shapilis. Egyptian vassals in Palestine took the opportunity to assert their independence. $(\mathrm{G}: 253-$ 256; Bc:256-263; H:110-III; vD:297-298)

Egypt became distracted by Libyan nomad attacks, against which Ramses fortified his western frontier. (G:256) Nevertheless, fighting went on in the debatable Egypt-Hittite buffer zone of Syria and Palestine. In Ramses' seventh year he returned to Palestine, campaigning through rebellious new kingdoms, such as Moab and Edom-Seir. $(\mathrm{G} \div 256 ; \mathrm{Bc} \div 263)$

Muwatallis was succeeded by his son Urhi-Teshub, or Mursilis III (I272I267), who returned the capital to Hattusas. (Bc:275-280) In Ramses' eighth and ninth years, I27I-I270, he invaded Syria again, penetrating the Orontes valley far to the north. $(\mathrm{G} \div 256-257 ; \mathrm{Bc} \div 263)$

Kadashman-Enlil II of Babylonia (1279-I265) apparently kept the peace with Assyria. (MR:275)

\section{BC. Tripolarः Egypt, Hatti, Assyria.}

An internal Hittite struggle for power pitted Mursilis III against his most powerful governor, his uncle Hattusilis III, who staged a successful coup against him, politely demoting him to a governorship in Syria, where he intrigued with Babylonia and perhaps Assyria. Hattusilis ordered him transferred elsewhere; Mursilis fled to Ramses II of Egypt, who gave him refuge in his isth year. $(\mathrm{G}: 257 ; \mathrm{Bc} \div 284-29 \mathrm{I} ; \mathrm{vD}: 298)$ 
Shattuara II raised a revolt in Mitanni against Shalmaneser I of Assyria, who responded with a conquest and genocide that put an end to Mitanni. Shalmaneser thereby acquired lands, skills and peoples with which Assyria was able to greatly increase its aggressive capabilities. Hattusilis of Hatti, seeking to placate Assyria, apparently abandoned Mitanni to its fate, and sought peace with Egypt. (MR:280-282; Bc:303-304; vD:298)

\section{BC. Tripolar: Egypt, Hatti, Assyria.}

In the twentieth year of Ramses II of Egypt (c. I260) he crushed a large revolt of the Irem in the south, retaining the gold of Nubia, where he built many new temples. By this time Avaris, renamed Pi-Ramesse, had been built up to serve Ramses' capital, and a Hittite peace envoy was received there. In his twenty-first year (c. I259) Ramses signed with Hattusilis III of Hatti a historic treaty of friendship providing for a status quo boundary, mutual assistance in war and rebellion, and extradition of political refugees; it proved to be the foundation of a permanent peace. International trade prospered again. (G:257, 26I; $\mathrm{Bc}: 306-3 \mathrm{I} 2 ; \mathrm{H} \div \mathrm{IIO}-\mathrm{II} 2 ; \mathrm{vD} \div 298)$

Hattusilis thereafter occupied himself with unsuccessful attempts to suppress raiding and rebellion in western Anatolia. (Bc:320-324) He, or rather his wife and equal Puduhepa, also contracted a dynastic alliance with KudurEnlil of Babylon (1263-1255), likely useful to both sides as a check to Assyria. $(\mathrm{Bc}: 328-329)$

\section{BC. Tripolar: Egypt, Hatti, Assyria.}

In Ramses' thirty-third year (c. I246) he made a marriage alliance with a Hittite princess, daughter of Hattusilis III, with joint celebrations at Damascus. In his 36 th year he entertained a Hittite prince seeking to organize imports of Egyptian grain. Ramses took advantage of the carefully-tended Hittite peace to embark upon a building program of unprecedented scope and scale. (G:257; $\mathrm{Bc}: 3 \mathrm{II}, 357 ; \mathrm{H}: \mathrm{II2}-\mathrm{II} 3 ; \mathrm{vD}: 299-3 \mathrm{OI})$

\section{BC. Tripolar: Egypt, Hatti, Assyria.}

Tudhaliyas IV of Hatti (I237-I228) faced rebellions in west and north. In some way, he managed to exclude from western Anatolia the influence of Aegean Ahhiyawa, often identified as Mycenean Greek "Achaea." (Bc:336-344)

In Ramses' forty-fourth year (c. I236) he married another Hittite princess. Egypt and Hatti remained at peace. (G:258)

Tukulti-Ninurta I of Assyria (c. 1244-I208) moved northward against the many ministates of Subari and Nairi (pre-Urartu), buffers to Hatti. Tudhaliyas IV ordered economic sanctions against Assyria and, when Subari fell, sent forces to assist Nairi, but was defeated, and Nairi was lost. Assyria then turned
Figure 11 - Palestine

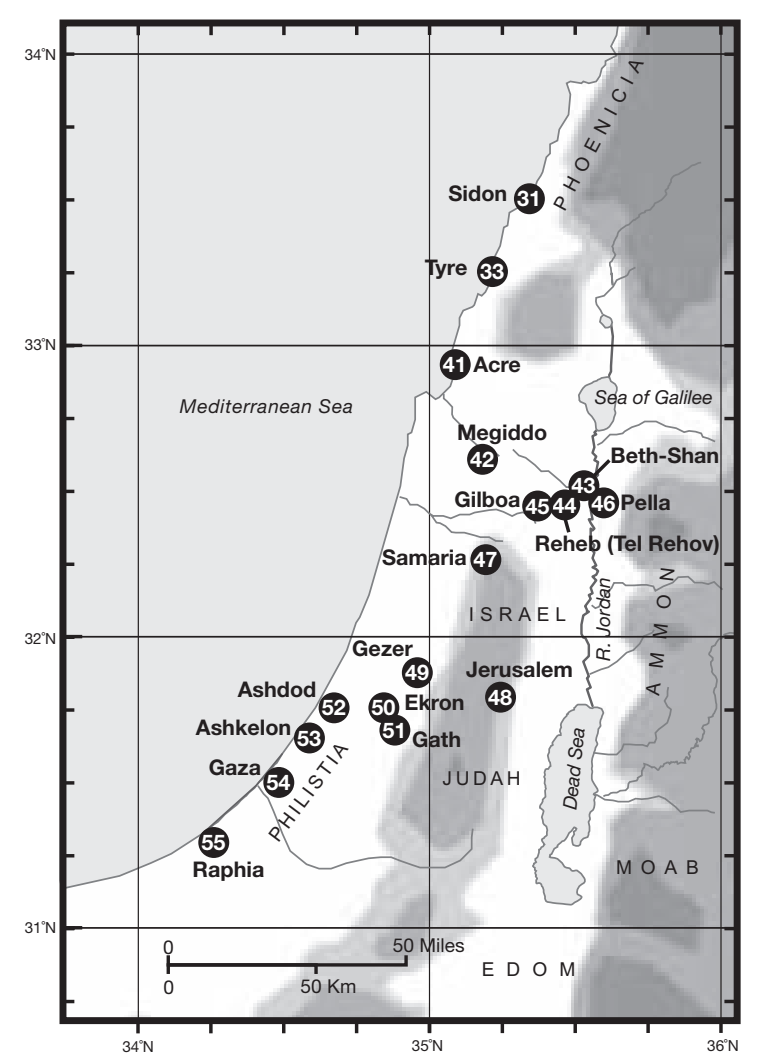

southward against Kashtiliash IV (c. I242-1235) of Kassite Babylon. TukultiNinurta conquered Babylonia to the sea, razed Babylon's walls, seized the king, appropriated its god Marduk, transplanted much of its population, and ruled Babylonia through governors. Fortunately for his neighbors, he was thereafter occupied with internal affairs, not least the retention of all these conquests. (MR:284-292; Bt:330; Bc:349-353; H\&S:I15; St:27)

\section{BC. Tripolar: Egypt, Hatti, Assyria.}

There may have been a coup and countercoup in Hatti whereby Tudhaliyas IV's cousin Kurunta briefly (I228-I227) seized the throne, so that Tudhaliyas had a second reign 1227-I209. (Bc:xiii, 354-355) Perhaps in this period, Tarhuntassa, the southern coast of Anatolia, broke away from Hatti. $(\mathrm{Bc}: 358,364)$

Perhaps it was in this period that Hatti conquered Cyprus (Alasiya) and made it tributary on account of its timber, copper, and/or strategic position for 
Figure 12 - Transcaucasia

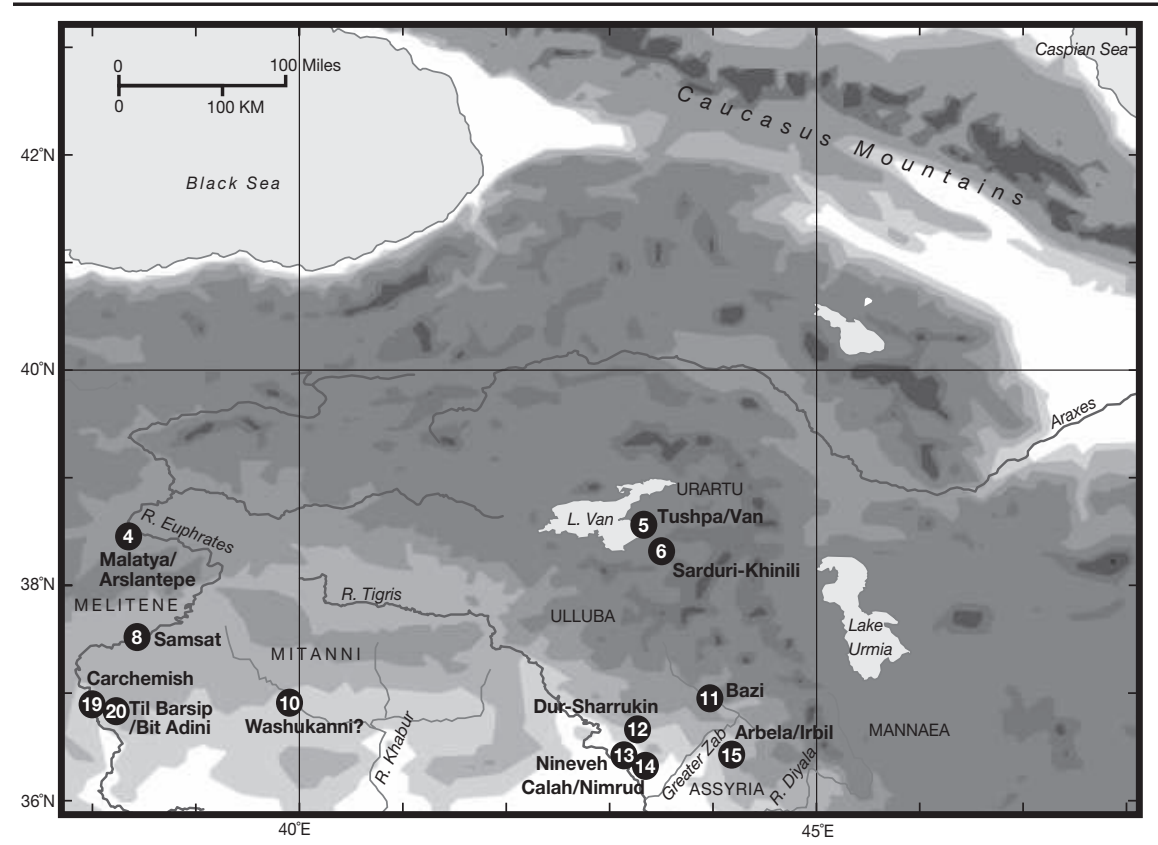

raiding or defending the grain import route from Egypt and Ugarit to the port of Ura in Cilicia. (Bc:356-358)

From 1228 to 1219 there was great disorder in Babylonia, with short-tenured rulers who faced Assyrian, Elamite and local Kassite pressures. Kidin-hutran of Elam took advantage of the Assyrian installation of successive client kings in Babylonia to overthrow one and rob another, capturing Der and Nippur during one invasion, Isin and Marad during the other. He and Elam then suddenly vanish from history, he not to return. (L:387-389; MR:288-290; W:443-444; $\mathrm{C} \& \mathrm{~S}: 39 ; \mathrm{P}: 23 \mathrm{I})$

\section{BC. Tripolar: Egypt, Hatti, Assyria.}

A Kassite royal scion, Adad-shuma-usur (I218-II89), was installed in Babylonia with local support. (MR:288; W:444; cf. L:388)

At the death of Ramses II, Egypt's power and international influence was very great. His son Merneptah (1212-I2O2) continued the friendship with Hatti, even sending grain to relieve a famine there; the boundary remained stable near the Damascus-Byblos line. (G:268)

\section{BC. Tripolar: Egypt, Hatti, Assyria.}

In 1208, Tukulti-Ninurta I of Assyria was murdered by a son in a revolt in
The Power Configuration Sequence of the Central World System which his new capital, Kar-Tukulti-Ninurta, was burnt. The revolt terminated Assyrias latest imperialist drive. Ashur-nadin-apli (I207-I204) and AshurNirari III (1203-I198) had short reigns, the latter perhaps contested. Babylonia under Adad-shuma-usur staged a recovery. (W:444, 449-450; H\&S:II5, I2I; St:27)

Merneptah of Egypt campaigned once into Palestine to suppress Ashkelon, Gezer, and Israel (which now appears in the historical record). He also suppressed a rebellion in Kush. (G:268)

The brief rule of Arnuwandas III of Hatti (1209-1207) saw new rebellion in the Hatti heartland. His successor Suppiluliumas II (1207-?) sought to restore the unity of the metropole; he lost control of vassal Ugarit, but reconquered south-coast Tarhuntassa and the once again rebellious southwest of Anatolia, and fought on sea and land for Alasiya/Cyprus. (Bc:36I-366)

Some force propelled a heterogeny of "Sea Peoples," identified with Achaeans, Lycians, proto-Etruscans, proto-Sicilians, and proto-Sardinians, from the Black Sea, Anatolia and/or the Aegean, first to Libya, where they combined forces with older inhabitants and earlier arrivals, and then eastward into the Egyptian Delta. In his fifth year (c. I208) Merneptah defeated, or subjugated, or co-opted, their first invasion, or colonization (they came with families, goods and cattle, and the surviving captives were settled in military colonies). (G:268269; $\mathrm{Bc}: 369,372 ; \mathrm{H}: 114, \mathrm{I16}$; vD:303)

The death of Merneptah of Egypt led to a succession crisis. A grandson of Ramses II, Amenmesse (I202-II99), viceroy of Nubia, usurped power. (G:269)

\section{BC. Multipolar: Egypt, Hatti, Assyria, Babylonia.}

Amenmesse was defeated and succeeded by a son of Merneptah, Seti II (II99-II96), who attempted to consign his predecessor's memory to oblivion. Internal preoccupations isolated Egypt from foreign affairs. At some time in the next twenty years, the Sea Peoples overran and devastated Hatti, Cyprus, Ugarit, Tyre and Amurru. (G:269; Bc:379; H:116; St:33)

Enlil-kudurri-usur (II97-II93) of Assyria was defeated by a Babylonian invading army. Ninurta-apil-Ekur, a pretender with Babylonian backing, then overthrew him and ruled (II92-II80). (W:444, 450-45I)

Seti was succeeded by his son Siptah (II96-II90), whose stepmother Twosre (II96-II88) served first as his regent, then, at his death, as his successor; Twosre "was active in the Sinai and Palestine." (G:270-271; H:I16-II7)

\section{BC. Bipolar: Egypt, Babylonia.}

Meli-Shikhu (II88-II74) succeeded Adad-shuma-usur in Babylonia, in a period of apparent quiet. (W:444-445) 
At about this time Elam revived as a power under Shutruk-Nahhunte I (II90-II55), who centralized historic stelae at Susa and built temples throughout the kingdom. (H:I2I-I27; Lb:482-485)

Without much commotion, one Setnakhte (II88-II86) usurped the Egyptian throne as redeemer from the usurper Twosre, beginning thereby Egypt's Dynasty 20 (II88-I069 BC). His son Ramses III (II86-II54) had more problems. In his fifth year (c. II82) the Libyans again invaded the western delta, where they were driven off or conscripted. (G:271; H:II8; vD:304-305)

\section{BC. Tripolar: Egypt, Babylonia, Elam.}

Ashur-Dan I (II79-II36?) succeeded to the Assyrian throne. (W:45I)

In the eighth year (c. II79) of Ramses III of Egypt, an alliance of Sea Peoples plus new groups including "Philistines" undertook a land invasion of Palestine, repelled by the Egyptian garrisons there, and a naval invasion of the eastern Nile Delta, rebuffed by Ramses' navy. The defeated immigrants were then once more accepted as subjects, whether as conscript soldiers or as settled colonists, e.g. the Philistines were colonized around Gaza and Ashkelon. (G:272; H:I18II9)

Between their last invasion of Egypt and this one, the Sea Peoples had led energetic lives: they had devastated Arzawa, Hatti, Alasiya, Ugarit, Alalakh, Carchemish and Amurru, though the Hittite viceroys of Carchemish maintained a succession and indeed claimed the Hittite kingship. While some sites in Hatti were burnt, the majority were apparently simply abandoned, as part of a general movement of peoples, in which the Kaska probably finally occupied the Hittite heartland; and a number of "neo-Hittite" or "Syro-Hittite" states, e.g. Melitene (cap. Malatya/Arslantepe), Commagene (Samsat), Gurgum (Marqasi), Hamath, emerged in southeastern Anatolia and Syria. (Bcะ367, 382, $384-385,388 ; \mathrm{vD}: 305)$

In the eleventh year (c. II76) of Ramses III of Egypt, he defeated a third wave of Libyan invaders, again with wives, children and cattle. Their goods were confiscated, they themselves enslaved and settled in colonies which actually attracted more Libyans as willing settlers. (G:272; H:II8-II9)

While the external invasions of Egypt now ceased, they were followed from Ramses' twelfth year ( $c$. II75) by severe internal economic problems, perhaps due to underlying food shortages, corruption, or priesthood-endowments, reflected in massive price inflation and deferrals of state provision-wages. (G:275; H:II9; $\mathrm{vD}: 305-306)$

Marduk-apla-iddina I (II73-II6I) ruled in Babylonia in a period of apparent quiet trade. (W:445) However, Shutruk-Nahhunte I of Elam, who was married to a daughter of the previous Babylonian king, also had designs on the Babylonian throne. $(\mathrm{P}: 208,233)$

\section{BC. Tripolar: Egypt, Babylonia, Elam.}

Over time, the disturbed Syro-Palestine area sorted itself out somewhat. There emerged in Palestine a land-sea trading confederation of Sea-People colonists led by the Philistines, initially Egyptian vassals. The colonists lorded it over the local south Canaanite population, and organized in a league of five cities, Gaza-Gath-Ashkelon-Ashdod-Ekron. The remaining independent Canaanites in Lebanon organized the maritime "Phoenician" states of Arvad, Byblos-Berytus, and Tyre-Sidon (Sidon later refounded Tyre as the Sidonian state capital). (A:507-526; St:33, 36)

Hittite refugees moved into northern Syria and formed Neo-Hittite kingdoms, with a northern league under Carchemish and five southern cities, Sa'mal (later Ya'diya), Hattina (Kinaluwa/Tell Tayinat), Arpad, Til Barsip, and Hamath. (St:33)

\section{BC. Tripolar: Egypt, Babylonia, Elam.}

Babylonia under Zababa-shuma-iddina (II60) was raided by Ashur-dan of Assyria and Shutruk-Nahhunte I of Elam. Enlil-nadin-akhi (II59-I157) then led Babylonian resistance to Elam until he was disastrously defeated: the Elamites, now under Kutir-Nahhunte (c. I155-1150), looted Babylon and various cult centers and put an end to the Kassite dynasty. Elam then turned to attack Assyria, whereupon a "second Isin dynasty" at once arose in Babylonia under Mardukkabit-ahheshu (II56-I139). (Lb:485-487; W:446-448, 45I; P:237-238)

Ramses III's economic troubles reached the point of inducing a historic workers' strike and protest march in his 29 th year. (G:275; H:II9; vD:306)

Ramses III was apparently the target of an assassination plot in his 3Ist year; Ramses IV (II54-II48) certainly succeeded to the Egyptian throne after a palace conspiracy. He was ambitious to be a temple-builder, but his program was cut short by early death. The office of high priest of Amun at Thebes began to grow more influential, independent, and hereditary. (G:276-277; H:120; $\mathrm{M}: 17 ; \mathrm{vD}: 306-307)$

\section{BC. Tripolar: Egypt, Elam, Assyria.}

Kutir-Nahhunte of Elam was succeeded by his brother Shilhak-Inshushinak (c. II5O-II20), who looted far to the northwest into Assyrian and Babylonian territory, and used the goods and slaves thus collected to undertake a major construction program. (Lb:488-492; C\&S:4I; P:238-247)

Ramses V (II48-II44) had a construction program as ambitious, and abortive, as that of his father; his reign was disfigured by a temple-corruption scandal. $(\mathrm{G}: 288 ; \mathrm{vD}: 307)$ 
Under his successor and uncle Ramses VI(II44-II36) Egyptian government was enfeebled and banditry grew. Nevertheless the empire still stretched to Megiddo and the Third Cataract of the Nile. (G:288; H:120)

\section{BC. Tripolar: Egypt, Assyria, Elam.}

The end of the long reign of Ashur-dan I of Assyria saw one son, MutakkilNusku (II34?), overthrow another, Ninurta-tukulti-Ashur (II35?), who fled to welcome and support in Babylonia. Mutakkil-Nusku soon gave way to his son Ashur-resha-ishi I (II33-III6), who fortified the country and fought off raiders from the north and west. (W:452-453)

Itti-Marduk-balatu of the second Isin dynasty ruled at Babylon (II38-II3I), in a quiet period. $(\mathrm{W}: 448)$

Ramses VII (II36-II28) built little; from his time, Egyptian rulers cease to be registered in the Sinai, whose copper mines had lost strategic importance because of the rise of iron. Grain prices peaked. (G:288; H:120, I22; vD:308)

\section{BC. Multipolar: Egypt, Elam, Assyria, Babylonia.}

Ninurta-nadin-shumi (II3O-II25) of Babylonia challenged Assyrian expansion around Arbela (Irbil), then backed off. (W:448)

Ramses VIII of Egypt (II28-II25) accomplished nothing of note. (G:289) His successor Ramses IX (II25-IIO7) had more time, works and inscriptions to his credit. (G:288-289)

Nebuchadnezzar I of Babylonia (II24-IIO3) fought against continued Elamite raiding. (W:454-455)

\section{BC. Multipolar: Egypt, Elam, Assyria, Babylonia.}

Hutelutush-Inshushinak succeeded his father Shilhak-Inshushinak in Elam c. II20, and continued temple-building. (C\&S:42; P:247) 456)

Babylonian attacks on Assyria were beaten off by Ashur-resha-ishi. (W:454,

Tiglath-pileser I of Assyria (III5-IO77) resurrected Assyrian imperialism, beginning a career of unprecedented conquest, massacre, terror, and deportation, which created a tribute/plunder-zone from Babylon to Nairi/Urartu to the Mediterranean. (H\&S:I2I; St:27) He first struck north, up the Tigris, against tribes which had recently been intruding, then against the Nairians near Lake Van, then westward to the Lebanon, conquering forty-two "lands" as he went. (W:457-46I; Bt:330-33I)

Arameans definitively appear in history and Syria: Tiglath-pileser I records 28 campaigns across the Euphrates against them. ( $\mathrm{Pi}: 82,84)$

In Egypt, there were strikes and nomad raids; the royal treasury showed signs of poverty. $(\mathrm{vD}: 308)$

\section{BC. Unipolar: Assyria.}

In Ramses IX's sixteenth year (c. IIIO), it was discovered that the increasingly brazen bandit gangs had been looting tombs in the Theban necropolis, an indication of the decline of the Egyptian state. (G:289-290)

At some time late in his reign Nebuchadnezzar I of Babylon invaded Elam, defeated Hutelutush-Inshushinak, pillaged Elam and put an end to its power for nearly 300 years. Nebuchadnezzar was succeeded by Enlil-nadin-apli (IIO2I099), who made no mark. (Lb:50I-503; W:455, 464; C\&S:43; P:252-255)

Ramses X (IIO7-IO98) of Egypt was apparently the last king to be recognized as in control of Nubia. He too faced a strike of unfed necropolis workers. (G:291; H:I23)

\section{BC. Unipolar: Assyria.}

Under Ramses XI of Egypt (1098-I069), famine, banditry and tomb robbery increased in Upper Egypt. So did the independent inclinations of the chief priests of Amun at Thebes, and of the viceroy of Nubia at Kush. (G:29I; H:I23; $\mathrm{vD}: 308)$

Marduk-nadin-ahhe of Babylonia (I098-IO8I) revived conflict with Assyria, raiding and looting. (W:46I)

\section{BC. Unipolar: Assyria.}

In Ramses XI's year 12, the viceroy Panehsy had brought Nubian troops to Thebes to restore order. About years 17-19, however, he began to fight first the high priest Amenhotep and then the royal army. Panehsy was driven back to Nubia, and henceforward was treated as an enemy to Egypt. (G:29I-292; $\mathrm{H}: 123-124 ; \mathrm{M}: 18)$

Tiglath-pileser I of Assyria raided all the way to Babylon, ruining without conquering. There was a great famine in Babylonia, which was invaded by desert Arameans, and king Marduk-nadin-ahhe vanished. (W:46I-462, 465)

\section{BC. Unipolar: Assyria.}

In some order, there appeared two new chief priests of Amun at Thebes, Piankh and Herihor. Over the next years, the first to appear successfully usurped power in Upper Egypt and Nubia, while one Smendes apparently acquired de facto control of Lower Egypt from Ramses XI's own capital PiRamesse. (H:I23-I24; vD:309 vs. G:292, 3II-312; M:I8-22, 34)

Piankh replaced Herihor, or vice versa, but Panehsy of Nubia remained in "rebellion," and was still fighting in the 28th year (c. IO7I); Nubia and its gold revenues were not recovered for Egypt. In I070 Piankh, or Herihor, was succeeded by his son Pinudjem I (IO70-IO32) (G:3II-312; M;34; H:I23-I24, I26; T:33I; vD:309) 
Tiglath-pileser I of Assyria had expanded his realm to Lebanon and made Byblos, Sidon and Arvad his vassals. (H:124) He was followed by the brief and unsung reign of Ashared-apil-Ekur (I076-1075) and the more active Ashur-belkala (I074-I057). (W:465, 467)

Marduk-shapik-zeri (1080-I068) worked to regenerate Babylonia. (W:465) However, Babylonia (and Assyria) would be kept preoccupied for the next hundred years by invasions and pressures from Aramean desert peoples (among them the Chaldeans, of future note). (St:27)

\section{BC. Unipolar: Assyria.}

The Phoenician cities of Sidon and Byblos had recovered somewhat from the Assyrian depredations, though their trade was curtailed by pressure from the Philistine confederation to the south. (Au:25, 29-3I) Egypt remained without influence in Palestine and Syria, and had to negotiate and pay for Phoenician goods that would previously have been a tributary gift; this weakness would last a hundred years. $(\mathrm{G}: 314)$

Ashur-bel-kala of Assyria fought successfully against Uruatri/Urartu, and may have campaigned to the Mediterranean. Marduk-shapik-zeri of Babylonia fought Arameans, and pledged mutual peace and good will with Assyria. (W:465-469; Bt:33I-332)

Upon the death of Ramses XI, Smendes (I069-IO43) founded a new dynasty in Lower Egypt (Dynasty 2I, 1069-945 BC), and created a new capital at Tanis from the dismantlings of the Ramessid capital Pi-Ramesse; 1069 is often taken as the end of the Egyptian New Kingdom and the start of the "Third Intermediate Period," in which a disunited Egypt became the local norm. Pinudjem I, the chief priest of Amun at Thebes, continued to rule Upper Egypt; his relations with the north were friendly, but the frontier was fortified. (G:292; H:I26; $\mathrm{T}: 333)$

An Aramean usurper, Adad-apla-iddina, seized control of Babylonia (1067-1046), and made a marriage alliance with Assyria, soon betrayed by an Assyrian attack. (W:466-467)

\section{BC. Unipolar: Assyria.}

In I055, Pinudjem I of Thebes took royal honors and named a son Masaharta to succeed him as chief priest. (G:312-313)

There was civil war in Assyria: with Babylonian help, Shamshi-Adad IV (1054-105I) defeated and deposed Eriba-Adad II (I056-I055). Both brief reigns saw some building repair work, but nothing grandiose. Shamshi-Adad was succeeded by Ashurnasirpal I (I050-I032). (W:469-470)
1050 BC. Multipolar: Assyria, Babylonia, Upper Egypt, Lower Egypt

с. 1050 вс, Gath unified Philistia and extended Philistine influence inland, dominating the Israelite hill country tribes. (E:23-24; St:34)

Addad-apla-iddina of Babylon was succeeded by Marduk-ahhe-eriba (1046-1045) and Marduk-ser-[x] (I044-1033). (W:470-47I)

In 1045, Pinudjem I of Thebes passed the chief-priesthood on to another son, Menkheperre (IO45-992). (G:312, 393; but cf. H:128)

Amenemnisu of Tanis (I043-IO39) and Menkheperre settled a north-south civil war by policies of mutual appeasement. (G:314)

\section{BC. Multipolar: Assyria, Babylonia, Upper Egypt, Lower Egypt,} Philistia.

Psusennes I of Tanis (I039-993) maintained the eastern frontier of Lower Egypt, and had a family alliance with chief priest Menkheperre of Thebes. (G:314-315 vs. T:333-334)

Nabu-shumu-libur (I032-IO25) succeeded in Babylonia, and Shalmaneser II (IO3I-IO2O) orderly succeeded his father Ashurnasirpal I in Assyria; the latter may have lost territory to Arameans. (W:470-47I; Gy:249)

\section{BC. Multipolar: Assyria, Babylonia, Upper Egypt, Lower Egypt,} Philistia.

In Babylonia, power passed from the Second Dynasty of Isin to a Second Sealand Dynasty from the Persian Gulf region, whose first ruler was SimbarShikhu (I024-I007). (W:47I-472)

\section{BC. Multipolar: Assyria, Upper Egypt, Lower Egypt, Philistia, Babylonia.}

Saul (c. IO2O-IOOO) led Israelite resistance to Philistine domination.

Apparently generally uneventful successions and reigns continued at Assyria under Ashur-nirari IV (IOI9-IOI4) and Ashurrabi II (IOI3-973), though the latter may have lost some land to Arameans. (W:470; Gy:249)

\section{BC. Multipolar: Assyria, Upper Egypt, Lower Egypt, Philistia, Babylonia}

Simbar-Shikhu of Babylonia was killed and the throne usurped by Eamukin-zeri (1007-1006). He was soon followed by Kashshu-nadin-akhi (Ioo6I004) under whom there was famine. E-ulmash-shakin-shumi (1003-987), the first king of a new brief Kassite dynasty from Bazi, whose reign saw improvement, renewed the old claim to be "king of the world," but did not noticeably implement it. (W:472-473; Bk:196) 


\section{BC. Multipolar: Assyria, Upper Egypt, Lower Egypt, Philistia,}

\section{Babylonia.}

C. IO०० вс Philistines defeated and killed Saul of Israel at Gilboa; he was eventually replaced in Israel by the bandit and Philistine vassal David (c. IOoo965). (E:24-25; St:34)

Amenemope of Tanis (993-984) and Smendes of Thebes (992-990) succeeded Psusennes I and Menkheperre respectively at about the same time, without incident. (G:393; cf.318)

At about this time, the Phrygians, probably one among the Sea Peoples who had overthrown the Hittite Empire c. I200 BC, organized their own kingdom around Gordium in west-central Anatolia, though little is heard of it till the 8th century. Also around this time, Arameans converted the north Syrian Neo-Hittite state Til Barsip into Aramean Bit Adini. By this time, the Sidonian state under Abibaal dominated Phoenicia. It had refounded, and now developed, the secure island port city of Tyre, which became the capital of Tyre/ Sidon. (K:74-75; Au:29, 3I-35; St:35, 36, 38)

In south Syria by this time, Damascus too had become Aramean, and the Aramean state of Zobah was the most powerful in the region. ( $\mathrm{Pi}: 89)$

\section{BC. Multipolar: Assyria, Upper Egypt, Lower Egypt, Philistia,} Babylonia, Tyre/Sidon.

Pinudjem II of Thebes (990-969) and Osorkon the Elder of Tanis (984978) reigned obscurely. (G:318)

The Babylonian Bazi dynasty was continued by Ninurta-kudurri-usur (986-984) and ended with Shirikti-Shuqamuna (984), who was replaced by an Elamite, Mar-bit-apla-usur (983-978). (W:473-474)

\section{BC. Multipolar: Assyria, Upper Egypt, Lower Egypt, Philistia, Babylonia, Tyre/Sidon.}

Siamun of Tanis (978-959) reactivated Egyptian diplomatic ties with Asia, and restarted the first significant building since Psusennes I. (G:318-319; $\mathrm{M}: 40)$

The relatively durable "eighth" dynasty of Babylon began with the rule of Nabu-mukin-apli (977-943), noted for Aramean invasions, weak government, and high food prices. (W:474; Bk:298)

Israel under David defeated c. 975 and permanently diminished Philistia, and defeated and dominated Aramean Zobah and Damascus. (Pi:89-95; E:5556; St:34-35)

Ashur-resha-ishi II (972-968) succeeded Ashurrabi II in Assyria. (W:470)
970 BC. Multipolar: Assyria, Upper Egypt, Lower Egypt, Babylonia, Israel, Tyre/Sidon.

Hiram I of Tyre/Sidon (969-935) united most of Phoenicia, was suzerain to Byblos and Arvad, and sent a delegation with gifts to David of Israel. (K:94-95; St:34, 36)

Siamun of Tanis took advantage of Israel-Philistine conflict to seize and devastate the Philistine city of Gezer, and then to make a marriage alliance by giving a daughter, and Gezer, to Solomon (c. 965-93I) of Israel. (G:319; H:I28; $\mathrm{M}: 41 ;$ St:34)

A Psusennes (969-945) succeeded to the chief priesthood at Thebes, which now fell into decline. (G:319, 393; H:128)

Tiglath-pileser II (967-935) ruled unremarkably in Assyria. (W:470)

\section{BC. Multipolar: Assyria, Upper Egypt, Lower Egypt, Tyre/Sidon,} Israel, Babylonia.

One Psusennes II (959-945) became the last Lower-Egyptian ruler at Tanis. If this was the same Psusennes as the Theban chief priest who had taken control of Upper Egypt in 969, as seems likely, Egypt was thereby reunited. The influence of Libyan tribal chiefs, the military leaders of the state, increased. (G:319, 393; H:I28)

Having signed a sweeping commercial treaty to their mutual advantage, Hiram I of Tyre/Sidon and Solomon of Israel created a joint PhoenicianIsraelite fleet to sail the Red Sea and perhaps the Indian Ocean, breaking the Egyptian monopoly on such trade and financing great public works projects. (K:97-IO2, I09-II4; Au:44-45; St:34, 36)

\section{BC. Multipolar: Assyria, Egypt, Tyre/Sidon, Israel, Babylonia.}

Shoshenq I (945-924), a Libyan from a colony at Bubastis, Great Chief of the Meshwesh, son-in-law of Psusennes II, and commander-in-chief of the Egyptian armies, succeeded to the Tanite throne by a military coup, and founded the new, vigorous "Bubastite" 22nd dynasty (945-715 BC). Shoshenq subverted Israel by giving sanctuary to the anti-Judahite rebel Jeroboam, and led an expedition south of Aswan, the last exercise of Egyptian influence over Nubia. (G:319,322, 334; M:4I-42)

Babylon was ruled by Ninurta-kudurri-usur II (943) and Mar-bit-ahheiddina (942-?), in a period whose obscurity may be due to Aramean pressures; nothing is heard of Babylonia until the last decade of the century. (Bk:299) 
940 BC. Multipolar: Egypt, Assyria, Israel, Tyre/Sidon.

C. 936 BC, Shoshenq I appointed his son Iuput as vicar of Upper Egypt (i.e., chief priest, army commander, and governor). (G:322; H:I28)

Balbazer I (or Baalmaazzar I, 935-919) succeeded Hiram I of Tyre/Sidon. (K:I16, I2I; St:36)

Ashur-dan II (934-912) resurrected Assyrian imperialism yet again. For the first time since Ashur-bel-kala (1074-I057), there were regular military campaigns recorded, mainly to the north against Arameans, with some lost land regained. (Gy:249; St:27)

Probably late in Solomon's reign, one Rezon, an Aramean of Zobah, seized Damascus and made it an independent state. (Pi:97)

\section{BC. Multipolar: Assyria, Egypt, Israel, Tyre/Sidon.}

At about this time, Solomon of Israel died, and Shoshenq I of Egypt allowed Jeroboam (c. 930-910) to return and seize power in Israel, except for Judah, which adhered to Solomon's son Rehoboam, and fought Israel. In 925, Shoshenq defeated first Judah (which he looted) and then Israel; on his return, he initiated a major building program with the loot. Egypt acquired suzerainty in Palestine; trade relations were reopened with now assertively independent Byblos, perhaps to counterbalance Tyre/Sidon. (K:121; G:323; M:23-26, 44-45; $\mathrm{T}: 336$; but cf. H:120; St:34)

Shoshenq's son Osorkon I (924-889) continued the temple-building program of his father, and replaced his brother Iuput as Theban chief priest with his own son Shoshenq II. (G:323-324)

\section{BC. Tripolar: Egypt, Assyria, Tyre/Sidon.}

Abdastratus (or Abd'ashtart, 918-910) succeeded Balbazer I of Tyre/Sidon. Tyre, its Red Sea connection through Judah constrained, was expanding a network of fortified trading ports westward into the Mediterranean, presumably protected by sea power. (K:I24-I26; St:36)

Adad-Nirari II of Assyria (9II-89I) continued the reconstruction of an Assyrian sphere of hegemony, fighting the Arameans in Hanigalbat to the west and the Nairi of Uruatri/Urartu to the north, and seizing territory from Shamash-Mudammiq of Babylonia, which thus re-emerges into history. (Bk:30I-302; Bt:332; Gy:249-25I; Bc:38I; St:27)

About this time Arameans took over Neo-Hittite Samal, turning it into Ya'diya. (St:35)

\section{BC. Tripolar Egypt, Assyria, Tyre/Sidon.}

Methusastratus (or Ashtart, 909-898) overthrew and succeeded Abdastratus at Tyre/Sidon. (K:127-128; St:36)
In 9oI, Adad-nirari II of Assyria began a series of campaigns against Arameans in Hanigalbat which lasted, with one break, to 894. (Gy:250)

\section{BC. Tripolarः Egypt, Assyria, Tyre/Sidon.}

Astharymus (or Astartrom, 897-889) succeeded Methusastratus of Tyre/ Sidon. (K:I28; St:36)

Around this time, Neo-Hittite Arpad becomes Aramean Bit Argusi. (St:35) Baasha of Israel disputed the border with Asa of Judah, who induced Ben-Hadad I of Aram-Damascus to attack Israel, destroying many Israelite towns. (K:IO7-II4)

In Osorkon's 27th year (c. 897), Asa of Judah rebelled successfully against Egyptian suzerainty and defeated a punitive expedition under one Zerah. $(\mathrm{G}: 323)$

In 894, Adad-nirari II of Assyria undertook an unresisted tribute-collecting expedition into the west. (Gy:25I)

About 892, Nabu-shuma-ukin I of Babylonia defeated Adad-Nirari II, reclaimed lost territories, and then established a marriage alliance with Assyria. (Bk:302)

Osorkon appointed his chief-priest son as co-regent about 890, but this Shoshenq II died without succeeding to the kingship. (G:324)

\section{BC. Multipolar: Egypt, Assyria, Babylonia, Tyre/Sidon.}

Tukulti-Ninurta II (890-884) slightly extended the Assyrian expansion, but mainly terrorized and plundered territories where Adad-nirari II had taken tribute. (Gy:25I-253)

Takelot I the Bubastite (889-874) appointed his son Iuwelot as Theban chief priest; Iuwelot proceeded to ignore his father, who left no monuments behind. (G:324)

At Tyre/Sidon, Phelles (888) killed Astharymus, and was killed and replaced (887-856) by the high priest Ittobaal (or Ethbaal), who undertook an assertive policy. Colonies were founded in Phoenicia and Africa; Tyre was fortified and its harbor improved. (K:129-166; Au:46-47, 50; St:36)

Ashurnasirpal II of Assyria began a long reign (883-859), during which his extractions, through terror, of immense tribute and forced labor, and his massacres to punish resistance, would range from Lake Van to the Mediterranean coast. (G:325-326; H\&S:I2I; St:27) In this decade, he campaigned south to suppress a rebellion instigated by Bit Adini (883), north to loot and collect in Urartu (883-882), and east to put down a tribal rebellion (88I-880). (Bt:333; Gy:253-254) 


\section{BC. Unipolar: Assyria.}

Osorkon II the Bubastite (874-850) named his cousin Harsiesis, son of Shoshenq II, chief priest at Thebes; Harsiesis soon elevated himself to kingship (870-860). (G:324-325; H:129)

Ashurnasirpal II campaigned south to collect tribute and put down a Babylon-inspired rebellion, north into Urartu to punish rebellion and collect tribute (879), and west to the Lebanon (877-867) to punish Bit Adini and collect tribute from Carchemish, Tyre/ Sidon, Byblos and Arvad. (Bt:333; Gy:254-257) He rebuilt Calah/Nimrud to replace Nineveh as his capital, and developed a centralized bureaucracy which would later turn the plundersphere into imperial provinces. (Gy:258; St:27)

Ahab of Israel (874-853) married Jezebel, daughter of Ittobaal of Tyre/ Sidon. (K:I3I)

\section{BC. Unipolar: Assyria.}

Ashurnasirpal II of Assyria campaigned west to receive tribute (866) and north into Urartu to loot and subdue (866 and later). (Bt:333-334; Gy:254255)

Ahab of Israel (874-853) was allied by marriage to Jehoshaphat of Judah (870-848), as well as to Ittobaal of Tyre/Sidon, who may have been similarly allied to Ben-hadad I of Damascus. (St:34, 35, 36)

\section{BC. Unipolar: Assyria.}

Osorkon II appointed his son Nimlot as chief priest at Thebes (c. 860), did a fair amount of building, and celebrated a royal jubilee festival in his $22 n d$ regnal year (c. 853). (G:325)

Shalmaneser III of Assyria (858-824; acceded 859) had more diplomatic and administrative flair than Ashurnasirpal II. Where possible, he began transforming vassal tributary states to imperial provinces; elsewhere, he regularized annual tribute. (H\&S:122; St:27)

Shalmaneser was also militarily active. In 859 , he sacked and burned Sugunia, a city of Arame the Urartian, who had apparently created a united Urartian state. (Bt:334) He campaigned annually in quest of complete control of northern Syria. (G:326) Shalmaneser was resisted at Lutibu in 858 by a north Syrian coalition of Aramean Bit Adini and Neo-Hittite Carchemish and others; from $857-855$ he subdued the coalition, conquered Bit Adini and made it a province. (Gy:260; H\&S:I23-I24; St:35)

In 856 or 855 , Shalmaneser again defeated Arame, and plundered and destroyed Arzashkun, another Urartian royal city, whose location, like that of Sugunia, remains in doubt. (Bt:335; Gy:264-265; St:39; Zimansky, 1998:passim)
Balbazer II (855-830) of Tyre/Sidon succeeded Ittobaal. (K:167)

Hadad-ezer of Aram-Damascus, Irhulena of Hamath, and Ahab of Israel formed a south Syrian coalition, and with contingents from Egypt, Ammon, Cilicia, Byblos and Arabia resisted Shalmaneser III of Assyria at the battle of Qarqar on the Orontes, 853. (Pi:126, I28; Gy:26I-262; G:326; H\&S:124; St:27, 35) Egyptian foreign policy in the next years remained focused on supporting Syro-Palestinian resistance to Assyrian imperialism. (G:326)

Apparently in fulfillment of a friendship treaty, in 85I-850 Shalmaneser intervened in a civil war in Babylon to restore the authority of its king, Mardukzakir-shumi I, though Babylon lost control of the eastern hill-tribe Kassites of Namri, and the Aramean Chaldeans in its southern cities. (Bk:305-306; Gy:266-267)

\section{BC. Unipolar: Assyria.}

Takelot II (850-825) continued Egyptian opposition to the expansion of Assyria, and the south Syrian coalition led by Hadad-ezer of Aram-Damascus resisted Assyria in 849, 848, and 845. (Pi:129-131; Gy:26I-262; G:327; $\mathrm{H} \& \mathrm{~S}: 124-125)$

Assyria then made a major plundering expedition through Urartu in 844, and fought the Kassites of Namri in the east, installing a vassal king. (Bt:336; $\mathrm{Bk}: 306 ; \mathrm{Gy}: 265-266)$

Hazael (c. 843-c. 800) seized power in Aram-Damascus. The south Syrian coalition dissolved. Hazael fought Jehoram of Israel, who was overthrown by his general Jehu (84I-8I4). Assyria attacked and defeated the now-isolated Aram, devastating its territory but not taking Damascus. Israel and Tyre/Sidon paid tribute to Shalmaneser III. (Pi:145-I48; Gy:262-263; G:326; St:35)

Takelot's reign left few traces in Egypt, perhaps because he continued his half-brother Nimlot as chief priest of Thebes, allowing him to control Middle Egypt as well. (G:327)

\section{BC. Unipolar: Assyria.}

Nimlot, chief priest of Thebes, died in Takelot II's tenth year (c. 840), and Takelot appointed the crown prince Osorkon as his successor. Thebes revolted in favor of a local candidate, another Harsiesis, and was crushed by Prince Osorkon. (G:327-328)

In 839-833 Shalmaneser III of Assyria reduced Cilicia to tributary vassalhood, plundering northwestward into the Taurus. (Gy:263) In 838 Assyria ravaged Damascene territory and took tribute from Tyre/Sidon and Byblos. (Pi:I48-I50; Gy:263)

In 835, Assyria overthrew its now-rebellious Kassite vassal at Namri. The 
Assyrians had their first encounter with the Medes, whose lands they accordingly looted. (Bk:306; Gy:266)

Thebes revolted again in the 15 th regnal year of Takelot II (c. 835), and a ten-year civil war ensued. (G:327-328)

Assyria campaigned against Urartu, now under Sarduri I, five times 832827, collecting much loot. (Bt:337-338; Gy:265-266)

Whilst Shalmaneser III campaigned east, north and northwest, Hazael of Aram-Damascus restored south Syrian independence, struck out against Assyrias vassal Jehu of Israel, and assailed Jehoash of Judah (835-796). (H\&S:I25; St:34-35, 39).

\section{BC. Unipolar: Assyria.}

Mattan I (or Mittin, 829-82I) succeeded Balbazer II of Tyre/Sidon. (K:167)

A dynastic revolt in Assyria broke out in 827; that and the death of Shalmaneser III in 824 suspended Assyrias imperial drive. Shamshi-Adad V (823-8II) restored order by 820 , but only by accepting subordination to Marduk-zakirshumi I of Babylon; and Assyria's western subject peoples fell away. (Bk:308; Gy:268-269; G:326; H\&S:125)

The civil war in Egypt ended in reconciliation in Takelot II's 24th regnal year $(c .827)$ but broke out again in his last year (c. 825). While Crown Prince Osorkon attempted to stem the revolt, the Bubastite throne was seized by his younger brother Shoshenq III (825-773). (G:328)

Ishpuini of Urartu and his son and co-regent Menua reorganized the pantheon, built fortresses, attacked and looted their neighbors, extended their domains, and fought Assyria without decisive result in 822 and 82I. (Bt:338-34I; $\mathrm{St}: 39)$

\section{BC. Multipolar: Lower Egypt, Upper Egypt, Babylonia, Aram- \\ Damascus, Urartu, Tyre-Sidon.}

Pygmalion (Pu'mayton) of Tyre/Sidon (820-774) succeeded Mattan I. He placed a copper-collecting colony at Citium in southeast Cyprus, and redirected Phoenician commercial connections westward, Tyre having become a major sea power. By tradition, Carthage was founded in 814, not as a mere imperial trading-post, but as a permanent colony, genuine yet independent and dissident, by the flight of a faction led by Pygmalion's sister Elissa/Dido. (K:I67, I88-I89; $\mathrm{Au}: 52)$

In Shoshenq III's sixth year (c. 820), the local candidate for chief priest Harsiesis re-emerged and took power at Thebes. In his eighth year, a royal prince, Pedubastis (818-793), proclaimed himself king, and established a 23rd
Dynasty in the Delta not far from Bubastis, at Leontopolis, which the Theban priests recognized. $(\mathrm{G}: 328)$

Three times (819, 818, 815?) Shamshi-Adad V of Assyria raided deep into Urartu for horses. He then revolted against Babylonia, now briefly under Marduk-balassu-iqbi and then Baba-aha-iddina, invading it four times (8I4-8II), capturing one king in 813 and the next in 812 , and claiming the kingship himself in 8II. Elam aided Babylonia, to no avail. (Bk:309; Gy:269-27I; H\&S:I25; $\mathrm{P}: 263)$

Shamshi-Adad V died in 8II, to be succeeded by his son Adad-Nirari III (810-783), in his first few years under the regency of his better-known mother Semiramis. Assyria became even more active militarily, apparently fighting annual campaigns, in Syria, Babylonia, Media and elsewhere, but failed to keep control of Babylonia, which fell into decades of independent disorder and international insignificance, even during the reigns of some few kings who restored some stability, held off invaders, and reopened trade. (Bk:309, 312; Gy:27I-273; $\mathrm{H} \& \mathrm{~S}: 126-127$; St:27)

Jehu of Israel having died in 814, Hazael of Damascus, who had lately taken Israel's Transjordanian lands, struck through Israel to capture Philistine Gath. (Mc:494; H\&S:I26)

810 BC. Multipolar. Assyria, Urartu, Damascus, Leontopolis (23rd Egyptian dynasty), Tanis-Bubastis (22nd), Upper Egypt.

Menua of Urartu (c. 810-c. 786) followed a policy of extensive fortressbuilding and civil engineering in expanding southeast, north, and west. (Bt:34I344)

Adad-Nirari III of Assyria campaigned in north Syria against Arpad in 805. (Pi:162-163)

Shoshenq III of Tanis-Bubastis re-appointed his elder brother prince Osorkon as chief priest of Thebes, with what effect is not clear, as Harsiesis resurfaces in Shoshenq's 25th year (c.80I). (G: 328) Pedubastis of Leontopolis was followed by Iuput I (804-783). (M:220; cf. G:328)

\section{BC. Multipolar. Assyria, Urartu, Damascus, Tanis-Bubastis (22nd} Egyptian dynasty), Upper Egypt, Leontopolis (23rd).

By his death c. 80o, Hazael of Damascus had subjugated Joahaz of Israel (814-798), Jehoash of Judah, and much of Philistia, thus creating an Aramean Empire. (Pi:15I-158; St:34-35)

Harsiesis of Thebes disappears in Shoshenq's 29th year (c. 797), leaving Upper Egypt to prince Osorkon. Shoshenq had control or suzerainty in much of the Delta-Libyan chiefdoms held the westernmost portions-and he was able to undertake several building programs. (G:328-329) 
Adad-Nirari III of Assyria campaigned in Syria in 796, receiving tribute from Philistia, and from Joash of Israel (798-782), who broke free of Damascus, recovered the Transjordanian territories lost to Hazael under Jehu, and c. 792 subjugated Amaziah (796-768) of Judah. (Mc:500-50I; H\&S:I27; E:74-75; St:34-35) Thereafter Adad-Nirari fought closer to Assyria and everywhere but in the west. (H\&S:127)

790 BC. Multipolar. Assyria, Urartu, Israel, Damascus, Leontopolis (23rd Egyptian dynasty), Tanis-Bubastis (22nd), Upper Egypt.

In $23^{\text {rd }}$ Dynasty Leontopolis, Shoshenq IV (783-777) succeeded Iuput I. (M:220; cf. G:328, 330)

An Elamite ambassador is reported at the Assyrian court in $784 .(P: 263)$ Assyrian central power had declined considerably by the end of the reign of Adad-Nirari, while Urartu under Argishti I (786-764) had become much stronger and aggressive, expanding northwest, northeast, east, and west. Shalmaneser IV (782-773) of Assyria had to fight six defensive campaigns against Urartu from 78I-774, and controlled Assyria itself only weakly. (Bt:344-346; $\mathrm{Gy}: 276-277 ; \mathrm{H} \& \mathrm{~S}: 128 ; \mathrm{St}: 39)$

\section{BC. Multipolar. Urartu, Assyria, Leontopolis (23rd Egyptian} dynasty), Tanis-Bubastis (22nd), Upper Egypt

Alara (c. $780-760)$ came to power as the seventh king-the first whose name has survived-of an Egyptianized, Amun-worshipping Kushite dynasty at Napata in Nubia; this Nubian dynasty would in due course become the 25th dynasty of Egypt. (G:334)

The $23^{\text {rd }}$ Dynasty Leontopolitan Osorkon III (777-749) succeeded Shoshenq IV. (M:220; cf. G:330) Shoshenq III of Tanis-Bubastis died in his 53rd regnal year, c. 773, to be succeeded in his 22nd Dynasty by Pami/Pimay (773767), who left no distinct impression on history. (G:329-330; M:220).

Assyria attacked and took tribute from "Hadianu" of Damascus in 773. (Pi:175) However, Ashur-dan III of Assyria (772-755) faced rebellions in Syria, and was not always able to mount an annual campaign. (Gy:277-278)

\section{BC. Multipolar. Urartu, Assyria, Tanis-Bubastis (22nd Egyptian} dynasty), Upper Egypt, Kush, Leontopolis (23rd).

Power in Babylonia was passing into the hands of the Chaldeans. (Bk:3IO312) Assyria waged unimpressive campaigns in Babylonias direction in 769 and 767; Ashur rebelled in 763-762, Arrapkha (Kirkuk) in 76I-760. (Gy:277-278)

Shoshenq V (767-730) succeeded Pami as 22nd Dynast of Tanis/Bubastis. At about that time the 23rd Dynasty Leontopolitan king Osorkon III somehow contrived to install his son Takelot III first as ruler of Heracleopolis, then as chief priest of Thebes, then $(c .765)$ as his own co-regent and heir apparent. A Meshwesh chiefdom at Sais was beginning the expansion in the western Delta which would eventually produce a 24th Dynasty. (G:330)

Sarduri II (764-735) succeeded Argishti I in Urartu, and continued an aggressive expansion westward toward north Syria. (Bt:348)

760 BC. Multipolar. Urartu, Assyria, Israel, Damascus, Leontopolis (23rd Egyptian dynasty), Tanis-Bubastis (22nd), Sais, Kush.

Kashta (760-747) of Kush acquired authority as far as Aswan, and assumed a royal title, from which time we may reasonably date the 25th (Kushite) Egyptian dynasty. (G:335) 23rd dynast Takelot III of Leontopolis (754-734) maintained overlordship in Upper Egypt via his sister Shepenwepet I. (G:33I; dates $M: 220$ )

Ashur-nirari V of Assyria (754-745) was the weakest and least active Assyrian king of the age, with no annual campaign in half his regnal years; Syria was slipping away; Assyrian governors were neglecting to acknowledge the king. (Gy:278-279; H\&S:128-I29)

Sarduri II of Urartu launched numerous looting, slaving, and subjugating expeditions in all directions. (Bt:348-349)

Jeroboam II of Israel (782-753) defeated, reduced, and perhaps annexed Damascus, which was replaced as a power in Aram by the more northern Arpad (Bit Argusi), whose king Matiel allied with Urartu against Assyria in 755. (Pi:177; St:34-35)

750 BC. Multipolar. Urartu, Israel, Kush (25th Egyptian Dynasty), Assyria, Arpad, Leontopolis (23rd), Tanis-Bubastis (22nd), Sais.

A weak Babylonian king, Nabu-shuma-ishkun (?-748), was succeeded by Nabonassar (747-734), who stabilized the Babylonian economy. (Bk:3II-3I2; Bkk:24)

Piankhy (or Piy, 747-716) succeeded his father Kashta in Kush and began a gradual push northward into Egypt. (G:335)

Sarduri II of Urartu continued his career as a raider, conqueror, looter and tribute-collector, mounting expeditions northward, southwestward, southeastward. (Bt:349-350)

Tiglath-pileser III (nominally 744-727, actually from 745) overthrew Ashur-nirari V, revitalized what is often called the "Neo-Assyrian Empire," and proceeded to reverse the contraction of Assyrian power. (Gyya:73; H\&S:I28I29)

His first campaign (745) was a quick raid swinging through northern, eastern and southern Babylonia, taking some territory, supplanting some suzerainties, transplanting some populations, but leaving king Nabonassar unfought 
and unshaken, indeed rather shored up by the reduction of Aramean and Chaldean pressures upon Babylon. This incursion inaugurated the Assyrian policy of mass transplantations of resisting peoples not just to the metropole for forced labor but into other rebellious regions, to obstruct coherent resistance. (Bkk:24; Gyya:8I, 83)

Tiglath-pileser's next campaign (744), eastward into the Zagros, conquered many small states and made them provinces, vassals or colonies. (Gyya:79-80)

Assyrias next campaigns (743-740) were aimed westward, to eliminate a Urartian sphere of influence which had grown up in northern Syria. Tiglathpileser defeated Urartu and its Syrian ally Arpad in 743, conquered Arpad by a three-year siege, and made the area an Assyrian province. (Bt:350; Gyya:75; St:37)

Humban-nikash (743-717) ruled Elam. (P:263)

\section{BC. Unipolar: Assyria.}

Sarduri II of Urartu now devoted his energies to building the fortress Sarduri-khinili. Tiglath-pileser III of Assyria campaigned north against Ulluba, a hostile buffer region south of Urartu, in 739, 738 and 736, annexing, provincializing, and colonizing it. (Bt:350-35I; Gyya:75)

Assyria next turned west, and received tribute from Tyre, Damascus, Carchemish, Hamath, Cilicia, Byblos and Israel. (Pi:183-I84; Gyya:75-76)

In 737 Tiglath-pileser campaigned eastward into the Zagros and Media, menacing Elam, shaving off a bit of Babylonia. (Gyya:80)

Assyria invaded and defeated Urartu in 735, even besieging the capital, Tushpa (Van), without success; still, the invasion, which was followed by border annexations, put an end to the northern troubles of Assyria. Rusa I of Urartu $(734 ?-714)$ worked to restore order and shore up the Assyrian frontier. (Bt:350352; Gyya:76; St:35-36, 39)

By about 735, Piankhy of Kush assumed a protectorate over Upper Egypt via his sister Amenirdis I, installed in a high religious post in Thebes. (G:335)

Philistine Gaza and Ashkelon, under embargo by Assyria, allied against it with the anti-Assyrian regimes in Israel (led by Pekah, 740-732), Damascus (led by Rezin), and Tyre-Sidon (led by Hiram II). Damascus and Israel combined against pro-Assyrian Ahaz of Judah (734-715). Tiglath-pileser III of Assyria undertook a second western campaign (734-732) to deal with the new coalition. Gaza, Ashkelon and Gezer were crushed; Israel was defeated and reduced by annexations (Gilead and Galilee) and deportations, but saved by Hoshea's pro-Assyrian coup; Damascus was besieged, taken, and annexed; Tyre begged pardon and paid tribute. (K:212-218; Pi:179-189; G:341; Gyya:7778; H\&S:132; St:34-35)
Tiglath-pileser extended the empire-building precedent of Shalmaneser III by systematizing the obligation, subjugation, truncation, and annexation of restive vassal states, the replacement and reorganization of their leaders and elites, and the deportation, importation and transplantation of peoples to create a "uniform heterogeneity" which might then be Assyrianized. (E:87-88)

Rudamun of Leontopolis briefly (734-73I) succeeded his brother Takelot III as 23rd Dynast, to be followed by Iuput II (73I-720), during whose tenure the rulers of both Hermopolis and Heracleopolis claimed royal status. (G:33I; dates $\mathrm{M}: 220$ ).

Nabonassar of Babylonia was orderly succeeded by Nabu-nadin-zeri (733732), who was overthrown by Nabu-shuma-ukin (732), in turn overthrown by the Chaldean Nabu-mukin-zeri (73I-729), whom Tiglath-pileser III expelled. (Bkk:24-25; Gyya:82; H\&S:133; St:27).

\section{BC. Unipolar: Assyria.}

Tiglath-pileser III crowned his career and himself by taking the throne of Babylon, receiving the royal honors there in 729. (Gyya:82)

Shoshenq V of the 22nd Egyptian (Bubastite) Dynasty was succeeded by his son Osorkon IV (730-715), whose authority was restricted to Tanis and Bubastis. The western half of the Delta was by now subject to the chiefs of Sais, the last of whom, Tefnakhte I (727-720) now proclaimed a new (24th) Dynasty. (G:330-33I; dates M:220)

Piankhy of Kush may have secured submission from Heracleopolis and Hermopolis; but Tefnakhte of Sais succeeded in bringing Hermopolis, plus the 22nd dynast Osorkon IV and the 23rd dynast Iuput II, into a coalition which proceeded to besiege Heracleopolis in Piankhy's 2Ist year (c. 727). Kush came to the rescue; the coalition was entirely defeated, and all five kings submitted to Piankhy, all but Tefnakhte in person. (G:335-340; M:73-85) Piankhy then returned to Napata, whereupon Tefnakhte resumed his independence and dominated the Delta once again. (G:340-34I)

Tiglath-pileser III was succeeded by Shalmaneser V (726-722), who faced an immediate revolt by his western vassals, Luli of Tyre/Sidon (c. 730-70I) and Hoshea of Israel (733-722). Hoshea was captured about 724 by Shalmaneser, who then besieged the Israelite capital Samaria and took it in 722. (Gyya:8586; H\&S:I33; St:27, 34, 36) But Shalmaneser was deposed in a rebellion and replaced by a usurper, Sargon II (72I-705). Babylon at once revolted under the Chaldean Merodach-baladan II (72I-7IO), who purchased assistance from Elam's Humban-nikash, who defeated Assyria at Der in 720. (Gyya:87-88,9798; $\mathrm{P}: 263-264)$ 
720 BC. Multipolar: Assyria, Elam, Babylonia, Tyre/Sidon, Urartu, Phrygia, Sais (24th Egyptian dynasty), Kush (25th), Leontopolis (23rd), Tanis-Bubastis (22nd).

Assyrias troubles in the south and east bred new troubles in the west. Yaubidi, a rebel leader in Syrian Hamath, induced Damascus and Samaria to revolt; Gaza and "Egypt" (i.e., most probably, Osorkon IV of Tanis/Bubastis) sent forces against Assyria in 720, but the resistance was badly defeated at Qarqar. Sargon II of Assyria destroyed Hamath, Ekron, and Gaza, and recaptured Samaria; Tyre submitted; Ahaz of Judah was reconfirmed as a tributary vassal; Egypt was defeated at Raphia; and there were massive transplantations at Samaria and Hamath. (Gyya:89; G: 342; H\&S:135; St:27-28)

By 720 and perhaps earlier, a central Anatolian kingdom, Phrygia, under one Mita or Midas, had grown to major-power status and was pressing on Cilicia and the Assyrian northwest imperial frontier. Urartu intrigued with Phrygia and Cilicia, and provoked rebellions against Sargon II of Assyria in the latter's northeast. Sargon campaigned there in 719, but was drawn off when Midas of Phrygia in turn provoked anti-Assyrian rebellions in their mutual borderlands 718-717; the most noteworthy result was the Assyrian conquest, annexation and colonization of revolted Carchemish. (Bt:352-353; Gyya:9I-94; $\mathrm{Mk}: 622-623 ; \mathrm{Bc}: 389)$

In Egypt, there were leadership changes which eventually provoked abrupt reunification. Bocchoris (720-715) succeeded Tefnakhte I as 24th dynast at Sais, and claimed, and probably possessed, hegemony over the Delta (G:34I); a Shoshenq VI may have succeeded Iuput II of the 23rd Dynasty at Leontopolis from 720-715 (M:220; cf. G:394).

From 717, Sargon was able to devote his idle hours to creating a new capital city, duly named for himself-Dur-Sharrukin (Khorsabad). (Gyya:Ioo-IO2) This did not impede his campaigning: in 716-715 Sargon turned east again, conquering into Urartu and Media. (Gyya:94-95) Assyrian forces also reached and garrisoned the border of Egypt proper in 716, but were bought off by tribute from Osorkon IV. (G:342-343; H\&S:134; St:27-28)

Piankhy of Napata died in 716, to be succeeded by his brother Shabaka (716-702). It was this Shabaka who in 715, eliminated Bocchoris, ended the 22nd, 23rd and 24th dynasties, and took control of all Egypt, ruling from Thebes a united state extending from the Mediterranean to the 6th Cataract. His Dynasty 25 (715-656 вс) begins the "Late Period" of Egyptian history. (G:343; St:3I)

Assyria meanwhile had turned northward, against Urartu under Rusa I, whose army was disastrously defeated at Uishdish in 714. Urartu was sacked up to Lake Urmia; Urartian governors revolted against Rusa; Cimmerian tribes invaded Urartu and defeated Rusa, who committed suicide. Rusa's successor, Argishti II (714-685) avoided fighting the Assyrians, and Urartu sank to minor power status. (Bt:353-356; Gyya:95-97; St:39)

Iamani of Philistine Ashdod seized power and revolted against Assyria in 712. Sargon II sent an army which captured Ashdod; Iamani fled to Egypt, but was handed over to Assyria by Shabaka. Assyria transplanted the people of Ashdod and Gath, annexed Philistia, and colonized it with new deportees. Appeasement bought Egypt more time to breathe, which Shabaka utilized to undertake an extensive religious building program throughout his new domains. (Gyya:89; G:343-345; St:28; cf. H\&W:136)

\section{BC. Unipolar: Assyria.}

In 710, Sargon II of Assyria set out against Elam under Shutruk-Nahhunte II (717-699) and Babylonia under Merodach-baladan II. In 709 he reconquered Babylon and declared himself king there, Merodach-baladan II having fled to the Elam borderlands, from which he endeavored to organize resistance. (Gyya:97-I0o; C\&S:46; P:265-266; St:28)

In 709, suffering from Assyrian raids on the Cilician border, Midas of Phrygia offered peace to Sargon II, who accepted with alacrity; diplomatic relations were established. (Gyya:92)

In 708, civil war broke out in Ellipi, which bordered Media, Elam and Assyria. Elam and Assyria intervened on behalf of rival claimants; Assyria prevailed. $(\mathrm{C} \& \mathrm{~S}: 46 ; \mathrm{P}: 267)$

In 707, Cimmerians invaded Urartu and defeated Argishti II, who nonetheless withstood Assyrian attacks, and even built new forts and waterworks. (St:39)

In 705, Sargon died fighting in the north. The confused succession of Sennacherib (704-68I) precipitated a new revolt in Babylon by Marduk-zakirshumi, who was himself displaced by Merodach-baladan II in 703. The Babylonian revolt, though assisted by Elam, was soon suppressed, and Assyria installed a puppet king in Babylon; resistance continued from the marshlands. (Gyyb:105-107; C\&S:46; P:267-268; St:28)

Shabaka of Egypt was succeeded by Piankhy's son Shebitku (or Shabtaka, 702-690), who followed a more assertive policy. In 70r Hezekiah of Judah organized an anti-Assyrian rebel coalition with Phoenicia (Sidon) and Philistia (Ashkelon); Egypt sent a force to Judah's assistance. Sennacherib defeated first Sidon, then Ashkelon, then Egypt (at Elteqeh in 70I); he besieged Jerusalem, deporting many, but accepted king Hezekiah's submission and tribute. Egypt and Assyria both drew back, the latter to cope with resistance in Babylonia. Judah survived as a tributary vassal; Luli of Tyre/Sidon transferred his capi- 
tal to Citium on Cyprus; Sidon surrendered to Sennacherib, who installed a more tractable vassal there. (K:246-249; Gyyb:109-III; G:346-347; H\&S:138; $\mathrm{Au}: 59 ; \mathrm{St}: 28,35,36)$

\section{BC. Unipolar: Assyria.}

\section{DATA SUMMARY}

The preceding narrative underlies the following sequence of 8I codings for the power polarity configurations of the Central system $1500-700$ BC (names of hegemons, and of polar states in unipolar and bipolar configurations, are mentioned parenthetically):

I500 BC. Multipolarity I490 BC. Multipolarity I 480 BC. Multipolarity I470 BC. Multipolarity I460 BC. Multipolarity I450 BC. Multipolarity I440 BC. Unipolarity (Egypt) I430 BC. Unipolarity (Egypt) I420 BC. Bipolarity (Egypt-Mitanni) I4IO BC. Bipolarity (Egypt-Mitanni) I400 BC. Unipolarity (Egypt) I390 BC. Multipolarity I380 BC. Hegemony (Egypt) I370 BC. Hegemony (Egypt) I360 BC. Hegemony (Egypt) I350 BC. Unipolarity (Egypt) I340 BC. Bipolarity (Egypt-Hatti) I330 BC. Multipolarity I320 BC. Multipolarity I3IO BC. Unipolarity (Hatti) I300 BC. Multipolarity I290 BC. Bipolarity (Egypt-Hatti) I280 BC. Bipolarity (Egypt-Hatti) I270 BC. Tripolarity I260 BC. Tripolarity I250 BC. Tripolarity I240 BC. Tripolarity I230 BC. Tripolarity I220 BC. Tripolarity I210 BC. Tripolarity I200 BC. Multipolarity
IIgo BC. Bipolarity (Egypt-Babylonia) II80 BC. Tripolarity II70 BC. Tripolarity II60 BC. Tripolarity II50 BC. Tripolarity II40 BC. Tripolarity II30 BC. Multipolarity II2O BC. Multipolarity IIIo BC. Unipolarity (Assyria) IIoo BC. Unipolarity (Assyria) I090 BC. Unipolarity (Assyria) I080 BC. Unipolarity (Assyria) I070 BC. Unipolarity (Assyria) I060 BC. Unipolarity (Assyria) I050 BC. Multipolarity I040 BC. Multipolarity I030 BC. Multipolarity IO20 BC. Multipolarity Ioı BC. Multipolarity I00o BC. Multipolarity 990 BC. Multipolarity 980 BC. Multipolarity 970 BC. Multipolarity 960 BC. Multipolarity 950 BC. Multipolarity 940 BC. Multipolarity 930 BC. Multipolarity 920 BC. Tripolarity 910 BC. Tripolarity 900 BC. Tripolarity 890 BC. Multipolarity

The Power Configuration Sequence of the Central World System

880 BC. Unipolarity (Assyria) 870 BC. Unipolarity (Assyria) 860 BC. Unipolarity (Assyria) 850 BC. Unipolarity (Assyria) 840 BC. Unipolarity (Assyria) 830 BC. Unipolarity (Assyria) 820 BC. Multipolarity 8Io BC. Multipolarity 800 BC. Multipolarity 790 BC. Multipolarity
780 BC. Multipolarity 770 BC. Multipolarity 760 BC. Multipolarity 750 BC. Multipolarity 740 BC. Unipolarity (Assyria) 730 BC. Unipolarity (Assyria) 720 BC. Multipolarity 710 BC. Unipolarity (Assyria) 700 BC. Unipolarity (Assyria)

This sequence is graphed in Figure 13, where the $\mathrm{Y}$-axis values are:

$0=$ Nonpolarity

$1=$ Multipolarity

$2=$ Tripolarity

3=Bipolarity

\section{DISCUSSION}

The 8I codings break down thus:

Empire: $0 / 81=0 \%$

Hegemony: $3 / 81=3.7 \%$

Unipolarity: $21 / 81=25.9 \%$

Bipolarity: $6 / 81=7.4 \%$

See Figure I4.

The extreme structures-Empire and Nonpolarity-were absent from the Central system during this period. Hegemony and Bipolarity were quite rare, Tripolarity more frequent than in other systems previously examined. Two codings-Multipolarity (44.4\%) and nonhegemonic Unipolarity (25.9\%) - were quite frequent; there was no preponderant structure.

These data allow us to address a number of recurrent issues in civilizations theory and world systems theory, some with practical contemporary ramifications.

I. Is it the case that all such systems tend to increase in centralization over time, moving e.g. from feudalism to states-systems to universal empires (and thence perhaps to ossification or collapse)? (Cf. Wight 1977, Spengler 1926-1928, Toynbee 1934-1954, Melko 1969.)

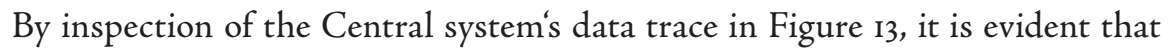
this (rather lengthy) period provides no support for the thesis of increasing centralization. 
Figure 13 - Central System Power Structures, 1500-700 BC

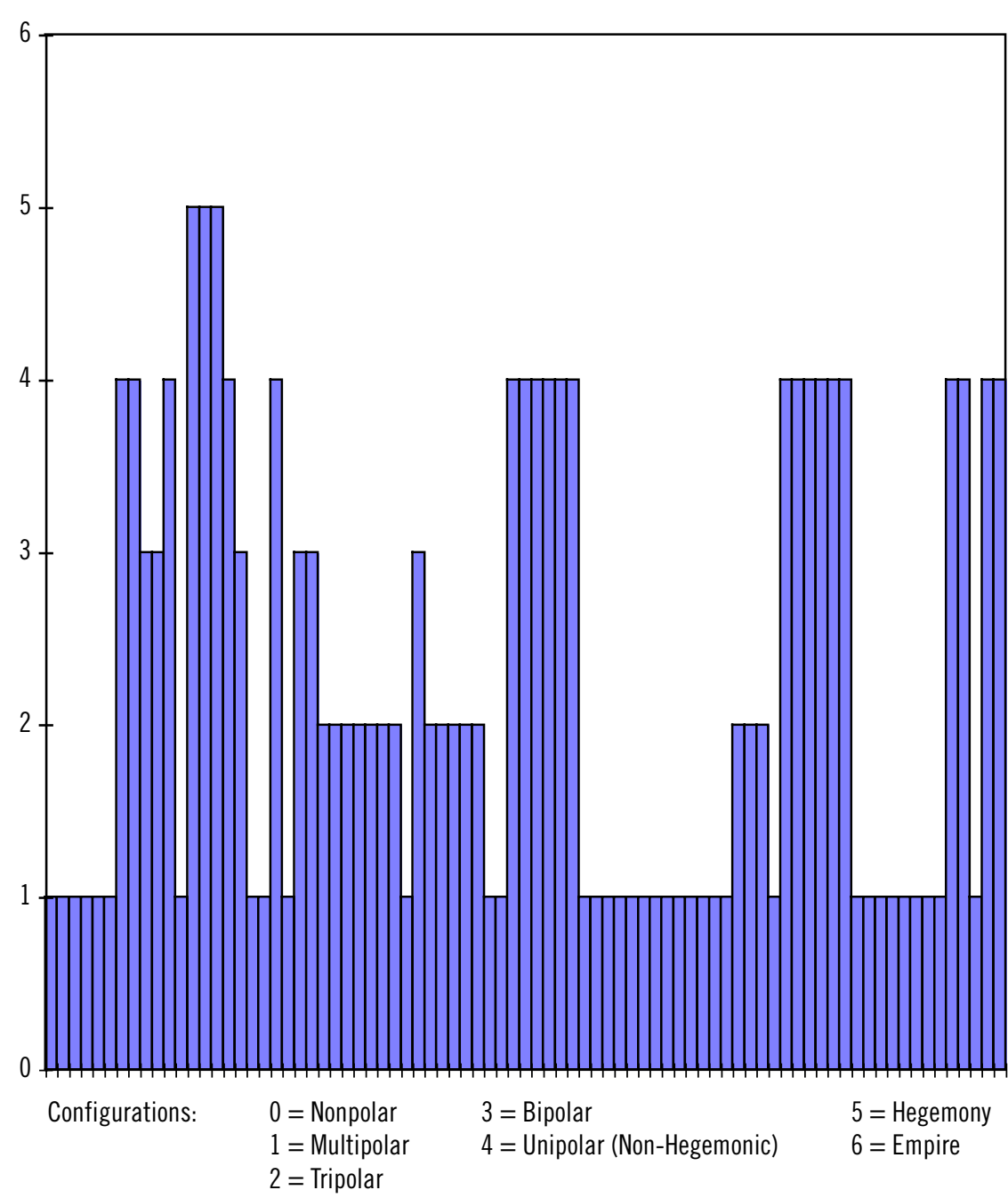

2. Is it the case that all such systems rather display cycles of centralizationdecentralization, with no normal "resting point" or terminus AD quem? (Toynbee, 196I)

This is Toynbee's revision of his earlier (1934-1954) "Hellenic" standard model for civilizations: it is a rhythmic alternation of systemic unifications and disruptions, in which political disunity, technoeconomic progress, and chronic warfare yield to forcible unification, pacification, stagnation, state overload, and a lapse into anarchy, which is however an "intermediate period" followed by a restoration of unity.

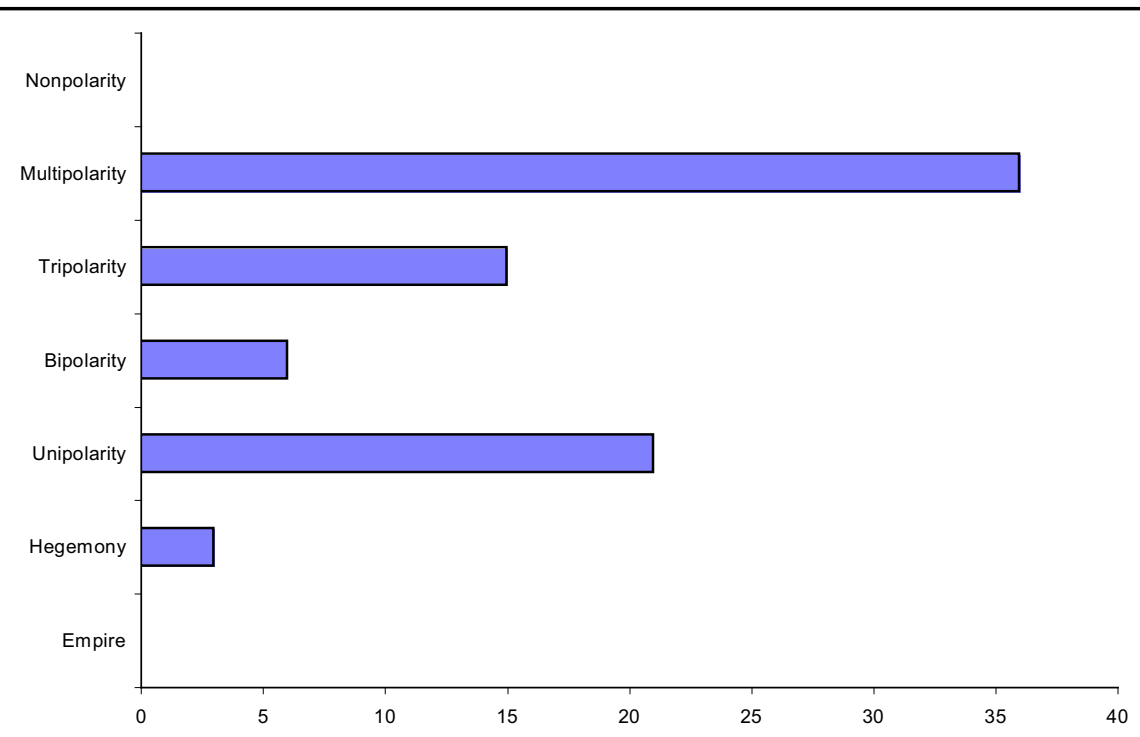

By inspection again, it seems clear that Toynbee's revised "Helleno-Sinic model" better agrees with the data than any increased-centralization theory.

3. Toynbee's revised model does not stipulate any particular decentralized forms as especially frequent representatives of their type, but the classic European balance-of-power literature does: multipolarity. (Gulick, 1955) Indeed some exponents of the theory expect multipolarity to be not merely one of two main forms, but the normal configuration of a world system: the current leaders of France, Russia and China seem to be among them. (Previous Chinese leaders, and many others-e.g. Dante Alighieri-would likely have stipulated empire as the norm; Kenneth Waltz might speak for the greater stability of bipolarity than multipolarity, but not necessarily for its normality.) Is it indeed the case that multipolarity is the normal and stable form of systemic political organization, so that deviations from it may be expected to be "rectified" by more or less automatic, as it were "physiological" homeostatic processes? (Cf. Cannon, I932; Claude, 1969; Dante, 1950; Waltz, 1979.)

A hypothetically modeled temporal trace of a stable multipolar world system's power configurations is given in Figure 15.

Comparing Figure 15 to Figure 13 , it seems that the behavior of the Central system during this period is reasonably consistent with the expectation of normal multipolarity held out by balance-of-power theory. 
Can we say how consistent? A simple quantitative test for the consistency of a qualitative data series with the hypothesis that multipolarity is the norm would be the fraction of the period spent in a multipolar condition. In this case, the data do not cover the entire period, but are taken at ten-year intervals, so the fraction of codings which are ( $\mathrm{I}=$ Multipolar) will have to serve as a first approximation. The approximation is likely to be rather good, but imperfect since the narrative showed some changes of configuration at smaller than tenyear intervals.

We may distinguish a "strong" from a "weak" version of multipolar-normalcy theory: a "strong" theory expects a majority of multipolar codings for any prolonged period; a "weak" theory expects a plurality only. The Central data are consistent with a multipolar norm, but a weak one: multipolarity accounts for $44.4 \%$ of all codings.

4. Toynbee's revised theory likewise does not stipulate any particular centralized form as the normal representative of its type. Other theories and traditions do: the classical Chinese view (e.g. Lo, 1999) posits empire; Wallersteinian world-systems theory (1983, 1984) expects hegemony; classical balance-of-power theory expects unipolarity as the normal direction, so perhaps the normal form, of deviation from multipolarity (e.g. Wight, 1946).

The $1500-700 \mathrm{BC}$ data are more consistent with the classical balance-ofpower theory than with the expectation of hegemony or empire as the main centralized polarity configuration: unipolarity $(25.9 \%)$ is the second most frequent coding, while empire (0.0\%) is absent and hegemony (3.7\%) minimal.

On the whole then, among the competing theories of the kinematics (the sequence of forms) of world systems, Toynbee's revised model, and the classical balance-of-power theory, have the best fit to the Central system data 1500-700 BC.

5. What of dynamics? What "forces" drive the changing of polarities over time? The classical balance-of-power theory expects that states will act to increase their power, but that centralization of the system by a single state will be resisted, and indeed prevented, by a "balancing" coalition of other states. (E.g. Waltz, 1979) Alternatives to balancing behavior do exist, however: "bandwagoning" (formation of a coalition with, or submission to, the rising power-e.g. Schweller, 1994) and "isolationist neutralism" (when states assailed by a rising power, whether simultaneously or seriatim, resist the assault rather than submit, but rely on self-help and refuse mutual aid). Did the Central system 1500-700 BC display multipolar balancing?

Figure 15 - Multipolar Stability

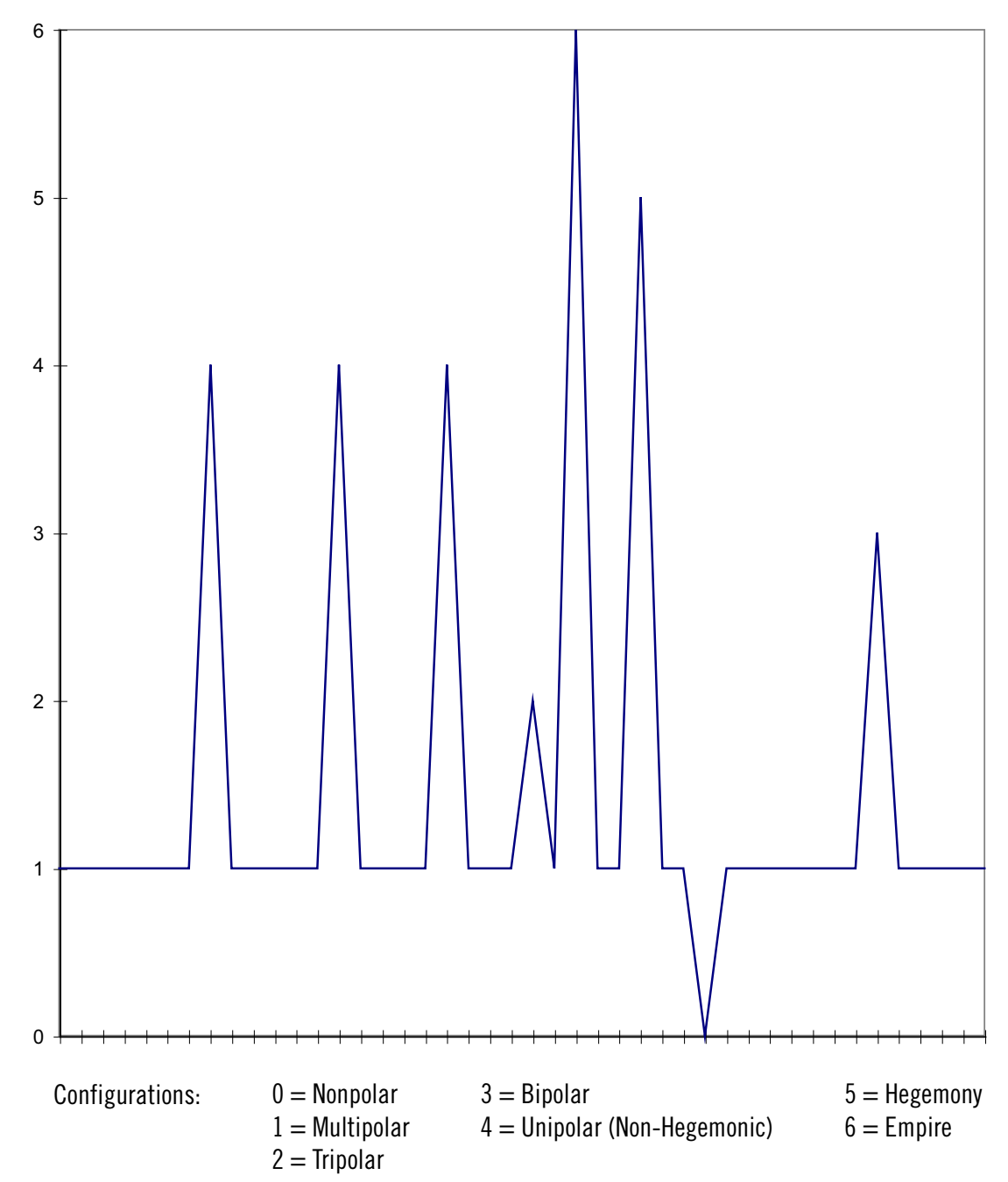

We must examine two sorts of eras for the answer to this question: multipolar epochs (to see if balancing coalitions formed and successfully resisted the rise of any single state to unipolar status); and unipolar (and hegemonic) epochs, to see if balancing coalitions formed to reduce the pre-eminent power, when they formed, and how the epochs ended.

There were protracted "runs" of multipolarity over the coding intervals I500-I450, 1050-940, and 820-750 вС. During these runs, little balancing 
occurred. Most states in these periods showed no systemwide ambitions, but confined themselves to localized warfare or were distracted by internal political concerns. One balancing coalition appeared, but failed: in the I460-I450 BC interval, Tuthmosis III of New Kingdom Egypt faced and defeated a defensive coalition at Megiddo in Syria-Palestine. Even so, Egypt was unable to secure control over Syria: stubborn, isolated local resistance by the states under attack, and not their unsuccessful joint resistance, preserved systemwide multipolarity in this interval.

What of the transitions from multipolarity to unipolarity (or hegemony) in the decades after $1450,1390,1320,1120,890,750$ and 720 , or in the opposite direction after 1400,1350 (via bipolarity), 1310, 1060, 830 and 730 ? Did coalitions form to resist or overturn the pre-eminent state?

a. I450-I440. The rise to unipolarity of Egypt under Tuthmosis III was met by bandwagoning; only Mitanni remained an obdurate enemy, and its resistance and subversive intrigues curtailed Egyptian power for a time, but without restoring multipolarity.

b. 1400-1390. Egyptian power under Tuthmosis IV was reduced, but not by a hostile coalition; Egyptian policy changed, to focus on external disengagement and internal improvement.

c. 1390-1380. Egypt's rise under Amenhotep III evoked bandwagoning.

d. 1350-1330. Egypt's standing declined under Akhenaten and Tutankhamen as external commitments were abandoned to focus on internal reforms and disputes.

e. I320-1310. The rise of Hatti under Mursilis II was met by unsuccessful isolationist neutralism.

f. I310-1300. Hatti's decline under Mursilis resulted from internal rebellions.

g. II2O-IIIO. Isolationist neutralism met, and failed to halt, the rise of Assyria under Tiglath-pileser I.

h. 1060-1050. It was civil war, not a hostile coalition, which eroded Assyrian predominance.

i. 890-880. Policies of isolationist neutralism failed to impede the rise of Assyria under Ashurnasirpal II.

j. $830-820$. By the 850 's, balancing coalitions began to form to resist Shalmaneser III, but they were unsuccessful: again it was civil war that reduced Assyrian pre-eminence after 830.

k. 750-740. Assyria under Tiglath-pileser III in the 750-740 interval repeated the $890-880$ pattern, facing and defeating isolated resistance.
1. 730-720. The 830-820 pattern also repeats: anti-Assyrian coalitions formed late, and failed; but civil war in Assyria relieved the other states of the Assyrian yoke.

m. 720-710. The rise of Assyria under Sargon II was resisted by a timely coalition, which however failed.

This record is thoroughly frustrating for classical balance-of-power theory. Most ascensions and predominances did not evoke resistance coalitions. Coalitions did form, often late, and always failed. It was the internal politics of the superpower-civil war or a deliberate inward turn-that repeatedly restored multipolarity.

\section{CONCLUSION}

Although the classical balance-of-power expectation of a multipolar normality is weakly met by the Central system in this period, the balancing behavior also expected by the theory is lacking or unsuccessful, and does not explain either the maintenance or the restoration of multipolarity: the expected dynamics are notably absent.

We have consequently not yet gotten beyond Toynbee's kinematics; we have no satisfactory dynamics of multipolar stabilization, at least not for this system in this period. We can neither fully accept nor entirely reject the utility of classical balance-of-power theory in explaining trajectories of world system behavior for this period. Probably we must settle for a more diffuse and less elegant explanation. The following points are directions that might be taken to further our theoretical penetration of the causes of the patterns found:

I. Kaplan (1957) attempted to educe behavioral "rules" which if complied with by actors in a system with a particular power configuration would tend to protract the tenure of that configuration. His examination of the balanceof-power "system" expects a relationship between conformance to rules (not all of which are coalition-centered) and maintenance of multipolarity.

2. In an era of agent-based modeling of complex systems, it may be worthwhile to resume the search for such rules of persistence and transformation, using the actual persistences and transformations of actual systems, including the Central system.

3. Paul Kennedy (1989) produced a historical review of modern European great powers which famously related relative military power to relative economic power (with a lag), and great-power decline to "imperial overstretch" - a failure to maintain a proper balance between material resources and military ambitions, and the assumption of strategic 
commitments which cannot all be simultaneously sustained. There appear to be some hints of imperial overstretch in the records of Egyptian and Assyrian challenges to multipolarity.

4. A Roman, Chinese or Stalinist imperial Grand Historian might find the persistence of multipolarity abnormal, and attribute it not to the prudent conduct of the assailed powers, but to the deficient imperialism of the rising power. The Grand Historian might remark on the personalistic and tributary dominance structures that prevailed during this period, and compare them unfavorably with his own bureaucratic-administrative hierarchy with its assimilative policies. Still, he might have found in the sporadic depopulations and transplantations performed by Hittites and Assyrians the germ of policies that could have put an end to an otherwise perennial inclination of subject peoples to revolt at the first opportunity.

5. An exponent of the "manually-operated" balance-of-power model (Claude, 1969) would recommend that we extend the dataset forward in time, expecting that balancing behavior would be learned rather than automatic, and that its learning might require a very long historical perspective. The accelerated formation of balancing coalitions toward the end of the current dataset might be seen as prefiguring further learning.

6. Kaplan's, Kennedy's, and the putative Grand Historian's and manualoperator's approaches are all agent-based. There is some visible tendency in this dataset for configurations to show durability; only a few codings $(9 / 8 \mathrm{I}=\mathrm{II}+\mathrm{I} \%)$ are "solitary" and unrepeated. There may be system-level features of complex systems (e.g. traditionalization) which contribute something to the explanation of both persisting and recurring polarity configurations. Perhaps systems are to some extent Newtonian-physical, or conservative, and will most likely be found at any time in the same configuration they showed at the time of last measurement. Perhaps systems are to some extent Aristotelian-physical, or reactionary, and will most likely be found at any time in the configuration they have occupied for most of their duration. Perhaps systems are to some extent Zipfian, so that the past distribution of a system's configurational frequencies best predicts the future distribution. The issue of sensitivity to prior conditions, sometimes labeled "path-dependence," clearly deserves investigation.

7. How stable was the systemic power structure in this epoch, whose history was by no means placid? One approach to this question is to look for changes in structure from one coding to the next. Excluding the first coding, of 80 codings only 25 (31.25\%) represent changes from the prior coding: the state of the system at time $t$ is an excellent predictor of its state at $\mathrm{t}+\mathrm{io}$ years.

8. Another way of contemplating the stability of power structures is to look for duration - for long runs. Aside from the initial 50 year run of multipolarity (necessarily truncated by and at the origin of the system) and the final so-year run of unipolarity (artificially truncated by the end of the study epoch), very long runs are noticeable: for multipolarity, a I20-year run $1050-930 \mathrm{BC}$ and an 80 -year run $820-750 \mathrm{BC}$; for unipolarity, a 50 -year run IIIO-IO60 BC, and a 50-year run 880-830 BC; for tripolarity, a 60-year run $1270-$ I2IO BC, a 40-year run II80-II40 BC, and a 20-year run 920-910 ВC. Even hegemony had a 20 -year run $1380-1360$ BC; only bipolarity managed nothing better than Io-year runs. Again excluding the initial run (of 6 codings) and final run (of 2 codings), at $4 \mathrm{I} / 73=56.1 \%$ of codings the system was in a run of at least 50 years, which could accordingly be taken as normal. The Central system seems to have been stable at longer than a generation, but less than a century.

9. Did the system evolve over time in any discernible direction? Comparing the first and last 40 of the $8 \mathrm{I}$ codings, it is evident that all the instances of hegemony and bipolarity occurred in the first epoch, as did $12 / 15=80 \%$ of the moments of tripolarity. On the other hand, $37 / 40=92.5 \%$ of the last epoch's codings are for unipolarity or multipolarity, as opposed to only $19 / 40=47.5 \%$ of the first epoch's codings. It seems that the Central system lost structural variety and became more stereotyped as it "matured" over the period under study. As between its two overall most prevalent phases, unipolarity and multipolarity, there was also a slight shift toward unipolarity, from $6 / 19=31.5 \%$ in the first epoch to $14 / 37=37.8 \%$ in the second.

IO. The stability of the system also increased: in the second epoch there were 8 structural shifts (in 39 opportunities), as opposed to 17 in the first, so that the system's state at time $t$ predicted its state at time $t+$ IO on $22 / 39=56.4 \%$ of the first 39 Io-year intervals, vs. $31 / 39=79.5 \%$ of the second 39 .

II. In short, over the intervals employed, the Central system I500-700 BC was rather stable, displayed limited variety from its inception, and lost variety over the period studied, becoming increasingly "stereotypic." The behavior of the system was superficially consistent with Newtonian, Aristotelian and Zipfian expectations. Dynamics which account for such tendenciesamong them hysteresis/inertia, traditionalization, memory traces, role learning-deserve consideration. 
These are by no means the only approaches that might be helpful in explaining the political trajectory of this world system, or others. It is likely to prove an interesting and exacting endeavor.

\section{APPENDIX Iः REGIONS AND PERIODS OF THE EARLY CENTRAL SYSTEM}

The epoch from 1500 to 700 has usually been periodized by region. In Egyptian history, that epoch comprises most of the New Kingdom period 1539-1069 (I8th Dynasty from Amenhotep I, r. 1514-I493, through Horemheb, r. 1323-I295; I9th Dynasty, I295-II88 BC; 20th Dynasty, II88-1069); all of the Third Intermediate Period, I069-715 BC (2Ist Dynasty, I069-945; 22nd Dynasty, 945-715, overlapped by local 23rd and 24th Dynasties, and the local beginnings of the 25th Dynasty); and the very beginning of the Late Dynastic Period (25th Dynasty solo, 715-onward).

In Sudanese history, 1500-700 вC includes the time of Egyptian Kush (c. I492-c. I070), and the rise of imperial Napata (from c. 780) to conquer Egypt, and become its 25th Dynasty.

In Mesopotamian history, 1500-700 вC encompasses most of the Kassite dynasty of Babylon (1595-II57 BC) and of the Mitanni kingdom of Washukanni (1550-I265); all of the 2nd Dynasty of Isin (I156-I025), the Middle Assyrian Empire (1362-IO77), the Aramean invasions (1076-934), and most of the NeoAssyrian empire (934-609).

In Anatolian history, 1500-700 BC includes the Hittite empire (c. I4IOI200), and the Phrygian period, from their invasion (c. I200-I000) to the kingdom of Midas (c. 730-695).

In Syria-Palestine-Canaan, 1500-700 BC encompasses the Sea peoples invasion ( $c_{+}$1200); all that is historical of the history of Israel and most of that of Judah; the rise and decline of Aram and Aramean Damascus (c. 1300-732); and most of the florescence of Phoenician Sidon ( $c_{+}$1200-627).

In Iranian history, $1500-700 \mathrm{BC}$ includes, in the southwest, the middle Elamite kingdom (c. I450-IIIO), and the beginning of the Neo-Elamite kingdom (c. 750-640); on the plateau, the Aryan invasion (c. 1500-850), the first rise of the Medes, their kingdom at Ecbatana (Hamadan), and their subjugation by Assyria (from $835 \mathrm{BC}$ ).

In Armenian history, $1500-700 \mathrm{BC}$ contains the Urartian invasion, settlement, and initial organization of kingdoms ( $c .1300-c .860)$, and much of the history of the kingdom of Urartu/Van (c. 860-584).

Excluded from the system for the purposes of this study are the land of Punt (Eritrean-Somali coast), in trade but apparently not politico-military connection with Egypt to at least c. II5O; the western Phoenician colonies of Lixus (in present-day Morocco), Gades and Sexi (Spain), and Utica and Carthage (Tunisia), partly because of uncertain initial dates and sizes, partly because of uncertainty concerning their political linkage to Phoenicia; Southern Arabia, for the same reasons; and (for most of the period) Northern Arabia, as a nomadic semiperiphery.

Greece is also excluded, as being part of a separate Aegean system during: the decline of Crete; Mycenean Late Helladic II (c. 1500-I400), Late Helladic III (c. I400-I200) and Late Helladic C (c. I200-IIOO); the Dorian, Aeolian and Ionian migrations (12th-Ioth centuries); the Greek Renaissance (900-800); the rise of Ionia (to 680), Sparta (900-700), Chalcis and Eretria (c. 800-700); and the initial colonization of Sicily and southern Italy (from c. 775).

\section{APPENDIX IIः CHRONOLOGICAL DECISIONS}

Among regional chronologies, Assyro-Babylonian come closest to being consensual, varying by one or two years rather than by decades. The latest Cambridge Ancient History chronologies have generally been preferred.

Egyptian chronology, on the other hand, is utterly contentious. At least nine recent or influential Egyptological chronologies compete: those of Hornung (1999), Grimal/Shaw (1992), the Cambridge Ancient History (1975), Hallo and Simpson (1998), Myśliwiec (2000), Murnane (1995), the Oxford Encyclopedia of Ancient Egypt (Redford, ed. 200I), Stearns (200I), and the Oxford History of Ancient Egypt (Shaw, ed., 2000). The Egyptian chronology elected herein largely follows Hornung (1999:xvi-xviii) through Tuthmosis IV, then Grimal/ Shaw (1992:392-394) through the Twenty-First Dynasty, and Grimal/Shaw supplemented by Myśliwiec (2000:220) for the 22nd-25th Dynasties. However, contrary to Hornung, the initial regnal date here used for Tuthmosis III is not that of his nominal accession (I479) but that of his actual ascent to power, Hatshepsut's final date (1458). Similarly, for Seti II, also eclipsed early in his nominal reign by the usurper Amenmesse, II99 replaces Grimal/Shaw's I202. The dates for Kashta of Napata (760-747) follow Murnane and HalloSimpson, since Myśliwiec gives none. It may be noted that Hornung's early i8th Dynasty dates are the same as those of Murnane, 1995:713-714, whose chronology was employed in the preceding paper in this series (2004).

The Hittite chronology used herein is that of Bryce (B:xiii-xiv, 4I4). Some synchronistic difficulties in his account would be resolved if Tudhaliyas I/II, or a separate Tudhaliyas I, were shown to have ruled before $1400 \mathrm{BC}, \mathrm{i}_{+} \mathrm{e}_{+}$contemporaneously with Amenhotep II of Egypt; and the reign of Arnuwandas I 
seems so very uneventful, and the succeeding reign of Tudhaliyas III so very disturbed, as to inspire some doubt. But otherwise his datings link to the Egyptian chronology we have elected with good consistency. They connect less well, however, with the Assyro-Babylonian chronology, especially its Babylonian section, and there is no obvious key at hand.

Middle Elamite chronology has lately become disturbed; I have used Potts' high chronology (1999), based on new synchronisms which force major changes in previously accepted datings. E.g., for Humban-numena, dated by Labat (L:384) at C. 1285-I266, Hinz (1972:112-I13) at 1300-1275, and Carter and Stolper (1984:234) at c. 1275, Potts (1999:209) proposes dates of 1350-1340.

\section{REFERENCE ABBREVIATIONS}

\section{A: Albright, 1975}

Au: Aubet, 2001

Ba: Bryan, 2000

Bc: Bryce, 1998

Bk: Brinkman, 1982

Bkk: Brinkman, 1991

Bt: Barnett, 1982

D: Drower, 1973

E: Ehrlich, 1996

G: Grimal, 1992.

Gd: Gadd, 1975

Gy: Grayson, 1982

Gyya: Grayson, 1991a

Gyyb: Grayson, 1991b

$\mathrm{H}$ : Hornung, 1999

Hz: Hinz, 1973

\section{BIBLIOGRAPHY}

Albright, W.F. (1975) “Syria, the Philistines, and Phoenicia." In Edwards, Gadd, Hammond and Sollberger, eds., infra, pp. 507-536.

Aubet, Maria Eugenia. (200I) The Phoenicians and the West: Politics, Colonies and Trade, 2nd ed. trans. Mary Turton. Cambridge: Cambridge University Press.

Barnett, R.D. (1982) “Urartu." In Boardman, Edwards, Hammond and Sollberger, eds., infra, pp. 314-37I.
H\&S: Hallo and Simpson, 1998.

K: Katzenstein, 1973.

L: Labat, 1975a.

Lb: Labat, 1975b

M: Myśliwiec , 2000

Mc: Mitchell, 1982

Mk: Mellink, 1991.

MR: Munn-Rankin, 1975

Pi: Pitard, 1987.

P: Potts, 1999

Si: Sicker, 2000.

St: Stearns, 2001

T: Taylor, 2000 .

vD: van Dijk, 2000

W: Wiseman, 1975.

Boardman, John, I.E.S. Edwards, N.G.L. Hammond, and E. Sollberger, eds. (I982) The Cambridge Ancient History. 2nd ed. Volume III, Part I. The Prehistory of the Balkans, and the Middle East and the Aegean world, tenth to eighth centuries B.C. Cambridge: Cambridge University Press.

Boardman, John, I.E.S. Edwards, N.G.L. Hammond, E. Sollberger, and C. B.F. Walker, eds. (I99I) The Cambridge Ancient History. 2nd ed. Volume III, Part 2. The Assyrian and Babylonian Empires and other States of the Near East, from the Eighth to the Sixth Centuries B.C. Cambridge: Cambridge University Press.

Brecke, Peter. (2000) "Moving Away from the Eurocentric Bias in the Study of Warfare." Paper prepared for the Annual Convention of the International Studies Association, Los Angeles, 2000.

Brecke, Peter. (200I) "Conflicts in South Asia and What They Contribute to Our Knowledge of the Role of System Structure in Violent Conflict." Paper prepared for the Annual Convention of the International Studies Association, Chicago, 200I.

Brinkman, J.A. (I982) “Babylonia c. I000-748 B.C.” In Boardman, Edwards, Hammond and Sollberger, eds., supra, pp. 282-3I3.

Brinkman, J.A. (I99I) "Babylonia in the shadow of Assyria (747-626 B.C.). In Boardman, Edwards, Hammond, Sollberger and Walker, eds., supra, pp. I-70.

Bryan, Betsy M. (2000) "The I8th Dynasty before the Amarna Period (c. I550-I352 BC)." In Shaw, ed., infra, pp. 218-27I.

Bryce, Trevor. (1998) The Kingdom of the Hittites. Oxford: Clarendon Press.

Cannon, Walter B. (1932) The Wisdom of the Body. New York: W.W. Norton.

Carter, Elizabeth, and Matthew W. Stolper. (I984) Elam: Surveys of Political History and Archaeology. University of California Press.

Chase-Dunn, Christopher, Susan Manning, and Thomas D. Hall. (2000) "Rise and Fall: East-West Synchronicity and Indic Exceptionalism Reexamined." Social Science History $24: 727-754$ http://irows.ucr.edu/research/citemp/ccr02/ccr02,htm

Chase-Dunn, Christopher, Daniel Pasciuti, Alexis Alvarez and Thomas D. Hall. Forthcoming. Waves of Globalization and Semiperipheral Development in the Ancient Mesopotamian and Egyptian World-Systems" in Barry Gills and William R. Thompson (eds.), Globalization and Global History Routledge. http://www.irows,ucr.edu/papers/irows14/irows14.htm

Cioffi-Revilla, Claudio, and David Lai. (I999) "War and Politics in Ancient China, 2700-722 B.C.: Measurement and Comparative Analysis." Paper prepared for the Annual Convention of the International Studies Association, Washington DC, I999.

Cioffi-Revilla, Claudio, and Todd Landman. (1999) "Evolution of Maya Polities in the Ancient Mesoamerican System." International Studies Quarterly, 43:559-598.

Cioffi-Revilla, Claudio, (200I) “The First International System: A Revised and Enhanced Data Set of Polities in the Ancient Near east, 5500 B.C. to I500 в.C." Paper prepared for the Annual Convention of the International Studies Association, Chicago, 200I. 
Claude, Inis W. (1962) Power and International Relations. New York: Random House. Dante Alighieri. (1950) On World-Government; or, De monarchia. Trans. Herbert W. Schneider. New York: Liberal Arts Press.

Drower, Margaret. (I973) "Syria c. I550-I400 B.C." In Edwards, Gadd, Hammond and Sollberger, eds., pp. 4I7-525.

Edwards, I.E.S., C. J. Gadd, N.G.L. Hammond, and E. Sollberger, eds. (I973) The Cambridge Ancient History. $3 \mathrm{rd}$ ed. Volume II, Part I. History of the Middle East and the Aegean Region c. 1800-1380 B.C. Cambridge: Cambridge University Press.

Edwards, I.E.S., C. J. Gadd, N.G.L. Hammond, and E. Sollberger, eds. (I975) The Cambridge Ancient History. 3rd ed. Volume II, Part 2. History of the Middle East and the Aegean Region c. 1380-1000 B.C. Cambridge: Cambridge University Press.

Ehrlich, Carl S. (1996) The Philistines in Transition: A History from ca. 1000-730 B.C.E. Leiden et al.: E.J. Brill.

Fox, William T.R. (1944) The Super-Powers. New York: Harcourt, Brace.

Frank, Andre Gunder, and Barry K. Gills, eds. (1993) The World System: Five Hundred Years or Five Thousand? London and New York: Routledge.

Gadd, C. J. (I975) "Assyria and Babylon, c. I370-I300 B.C." In Edwards, Gadd, Hammond and Sollberger, eds., supra, pp. 2I-48.

Grayson, A.K. (I982) "Assyria: Ashur-dan II to Ashur-Nirari V (934-735 B.C.)." In Boardman, Edwards, Hammond and Sollberger, eds., supra, pp. 238-28I.

Grayson, A.K. (I99Ia) "Assyria: Tiglath-pileser III to Sargon II (744-705 B.C.)." In Boardman, Edwards, Hammond, Sollberger and Walker, eds., supra, pp. 7I-IO2.

Grayson, A.K. (I99Ib) "Assyria: Sennacherib and Esarhaddon (704-669 в.C.)." In Boardman, Edwards, Hammond, Sollberger and Walker, eds., supra, pp. I03I4I.

Grimal, Nicolas. (1992) A History of Ancient Egypt. Trans. Ian Shaw. Oxford: Blackwell.

Gulick, Edward Vose. (I955) Europe's Classical Balance of Power. New York: Norton.

Hallo, William W., and William Kelly Simpson. (1998) The Ancient Near East: A History. New York: Harcourt Brace Jovanovich.

Hinz, Walther. (1973) The Lost World of Elam. New York: New York University Press.

Hornung, Erik. (I999) History of Ancient Egypt: An Introduction. Trans. David Lorton. Ithaca, NY: Cornell University Press.

Hui, Victoria Tin-bor. (2000) "Rethinking War, State Formation, and System Formation: A Historical Comparison of Ancient China (659-22I BC) and Early Modern Europe (I495-I8I5 AD)." Ph. D. dissertation: Columbia University.

Hui, Victoria Tin-bor. (200I) "Rethinking the Hobbesian Metaphor for International Politics: Comparing the Hobbesianness of Ancient China and Early Modern Europe." Paper prepared for the Annual Convention of the International Studies Association, Chicago, 200I.

Hui, Victoria Tin-bor. (Forthcoming) War and State Formation in Ancient China and Early Modern Europe. Cambridge University Press.
The Power Configuration Sequence of the Central World System 7I9

Kaplan, Morton A. (1957) System and Process in International Politics. New York: John Wiley.

Katzenstein, H. Jacob. (I973) The History of Tyre. Jerusalem: Schocken Institute for Jewish Research.

Kennedy, Paul. (1989) The Rise and Fall of the Great Powers: Economic Change and Military Conflict from 1500 to 2000. New York: Vintage Books.

Labat, René. (I975a) "Elam c. I600-I200 в.C." In Edwards, Gadd, Hammond and Sollberger, eds., supra, pp. 379-4I6.

Labat, René. (1975b) "Elam and Western Persia c. I200-1000 в.c." In Edwards, Gadd, Hammond and Sollberger, eds., supra, pp. 482-506.

Lo Kuan-Chung. (1999) Romance of the Three Kingdoms. Trans. Moss Roberts. University of California Press.

Melko, Matthew. (1969) The Nature of Civilizations. Bostonः Porter Sargent. Mellink, M. (I99I) "The native kingdoms of Anatolia." In Edwards, Gadd, Hammond, Sollberger and Walker, eds., supra, pp. 619-665.

Mitchell, T.C. (1982) "Israel and Judah from Jehu until the period of Assyrian domination (84I-C. 750 B.C.)." In Boardman, Edwards, Hammond and Sollberger, eds., supra, pp. 488-510.

Munn-Rankin, J.M. (I975) “Assyrian Military Power I300-I200 B.C.” In Edwards, Gadd, Hammond and Sollberger, eds., supra, pp. 274-306.

Murnane, William J. (1995) "The History of Ancient Egypt: An Overview." In Sasson, ed., infra, pp. 69I-7I7.

Myśliwiec, Karol. (2000) The Twilight of Ancient Egypt. Trans. David Lorton. Ithaca, NY: Cornell University Press.

Pitard, Wayne T. (1987) Ancient Damascus. Winona Lake, Indiana: Eisenbrauns.

Potts, D.T. (1999) The Archaeology of Elam. Cambridge: Cambridge University Press.

Ranke, Leopold. (I950) “The Great Powers." In Theodore H. Von Laue, Leopold Ranke: The Formative Years, Princeton University press, I8I-2I8.

Redford, Donald B., ed. (200I) The Oxford Encyclopedia of Ancient Egypt. Vol. I. Oxford University Press.

Rosecrance, Richard N. (1963) Action and Reaction in World Politics. Boston: Little Brown.

Schweller, Randall. (I994) "Bandwagoning for Profit: Bringing the Revisionist State Back In.” I9 International Security, 72-107.

Shaw, Ian, ed. (2000) The Oxford History of Ancient Egypt. Oxford: Oxford University Press.

Sicker, Martin. (2000) The pre-Islamic Middle East. Westport, Conn: Praeger.

Spengler, Oswald. (1926-I928) The Decline of the West, trans. Charles Francis Atkinson. New York: Knopf.

Stearns, Peter N., ed. (200I) The Encyclopedia of World History. 6th ed. Boston: Houghton Mifflin.

Taylor, John. (2000) “The Third Intermediate Period." In Sasson, ed., supra, pp. $330-368$. 
Thompson, William R. (200I) “Trade Pulsations, Collapse, and Reorientation in the Ancient World." Paper prepared for the Annual Convention of the International Studies Association, Chicago, 200I.

Thompson, William R. (2002) "Testing an Instability Theory in the Ancient Near East." 46 Comparative Civilizations Review (Spring 2002), pp. 34-78.

Toynbee, Arnold J. (1934-I954) A Study of History, vols. I-X. Oxford University Press.

Toynbee, Arnold J. (196I) Reconsiderations, Oxford University Press.

van Dijk, Jacobus. (2000) “The Amarna Period and the Later New Kingdom." In Shaw, ed., supra, pp. 272-313.

Wallerstein, Immanuel. (1983) Historical Capitalism. London: Verso.

Wallerstein, Immanuel. (I984) The Politics of the World-Economy. Cambridge University Press.

Waltz, Kenneth N. (1979) Theory of International Politics. New York: Random House.

Wight, Martin. (1946) Power Politics. London: Royal Institute of International Affairs.

Wilkinson, David. (I987) “Central Civilization," I7 Comparative Civilizations Review (Fall), pp. 3I-59.

Wilkinson, David. (I995) “Civilizations are World Systems.” In Stephen K. Sanderson, ed., Civilizations and World Systems, Palo Alto: Altamira, pp. 248260.

Wilkinson, David. (I996) "Configurations of the Indic States System.” 34 Comparative Civilizations Review (Spring), pp. 63-II9.

Wilkinson, David. (I999a) "Power Polarity in the Far Eastern World System 1025 BC-AD I 850: Narrative and 25-Year Interval Data." 5 Journal of World-Systems Research no. 3 (Fall). http://jwsr.ucr.edu

Wilkinson, David. (I999b) "Unipolarity without Hegemony." International Studies Review no. 2 (Summer), pp. I4I-I72.

Wilkinson, David. (200I) "Problems in Power Configuration Sequences: The Southwest Asian Macrosystem to I500 вС." I7 Comparative Civilization, pp. I-I3.

Wilkinson, David. (2004) "Power Configuration Sequences in the Northeast African World System to I500 BC." 50 Comparative Civilizations Review (Spring), pp. 82-104.

Wiseman, D.J. (1975) "Assyria and Babylonia c. I200-1000 B.C." In Edwards, Gadd, Hammond and Sollberger, eds., supra, pp. 443-48I.

Zimansky, Paul E. (1998) Ancient Ararat. Delmar, NY: Caravan. 